\title{
Pseudostriatella (Bacillariophyta): a description of a new araphid diatom genus based on observations of frustule and auxospore structure and $18 \mathrm{~S}$ rDNA phylogeny
}

\author{
Shinya Sato ${ }^{1 *}$, David G. Mann ${ }^{2}$, SAtoko Matsumoto $^{3}$ and Linda K. Medlin ${ }^{1}$ \\ ${ }^{1}$ Alfred Wegener Institute for Polar and Marine Research, Am Handelshafen 12, D-27570 Bremerhaven, Germany \\ ${ }^{2}$ Royal Botanic Garden, Edinburgh EH3 5LR, Scotland, United Kingdom \\ ${ }^{3}$ Choshi Fisheries High School, 1-1-12 Nagatsuka Cho, Choshi City, Chiba, Japan
}

\begin{abstract}
S. Sato, D.G. Mann, S. Matsumoto and L.K. Medlin. 2008. Pseudostriatella (Bacillariophyta): a description of a new araphid diatom genus based on observations of frustule and auxospore structure and 18S rDNA phylogeny. Phycologia 47: 371-391. DOI: 10.2216/08-02.1

Pseudostriatella oceanica gen et. sp. nov. is a marine benthic diatom that resembles Striatella unipunctata in gross morphology, attachment to the substratum by a mucilaginous stalk and possession of septate girdle bands. In light microscopy, $P$. oceanica can be distinguished from $S$. unipunctata by plastid shape, absence of truncation of the corners of the frustule, indiscernible striation and absence of polar rimoportulae. With scanning electron microscopy, $P$. oceanica can be distinguished by a prominent but unthickened longitudinal hyaline area, pegged areolae, multiple marginal rimoportulae and perforated septum. The hyaline area differs from the sterna of most pennate diatoms in being porous toward its expanded ends; in this respect, it resembles the elongate annuli of some centric diatoms, such as Attheya and Odontella. 18S rDNA phylogeny places $P$. oceanica among the pennate diatoms and supports a close relationship between $P$. oceanica and $S$. unipunctata, but the genetic distance between them, coupled with the morphological differences, justifies separation at genus level. However, the affinity of the $P$. oceanica $-S$. unipunctata clade remains unresolved both in molecular and in morphological study. Both genera are only distantly related to Hyalosira and Grammatophora, despite similarities in frustule structure and growth habit, arguing against their inclusion in the same family. The auxospore is covered with series of transverse and longitudinal bands, but the structure and arrangement of these bands appear to be more similar to the properizonia of some centric diatoms than to the classic type of perizonium seen in other pennate diatoms; a few scales are also present. The differences between properizonia and perizonia are discussed.
\end{abstract}

Key Words: 18S rDNA, Araphid diatom, Auxospore, Evolution, Fine structure, Morphology, Perizonium, Phylogeny, Pseudostriatella oceanica, Striatella, Taxonomy

\section{INTRODUCTION}

Benthic diatoms are ubiquitous in shallow coastal environments and are one of the most taxonomically diverse groups of organisms in estuarine ecosystems (Sullivan \& Currin 2000). Because of their high primary production rates, benthic diatoms play an important role in the functioning of benthic trophic webs in intertidal mudflats and shallow-water ecosystems of temperate to tropical regions (Cahoon 1999; Underwood \& Kromkamp 1999). Araphid pennate diatoms (diatoms with a sternum but lacking a raphe system; see Terminology) are important components of these coastal assemblages, particularly among communities attached to macrophytes and macroalgae, animals, rocks and sand grains (Round et al. 1990). Taxonomically, araphid diatoms have long been neglected, perhaps because of their morphological simplicity; according to Round et al. (1990), 'in many ways the classification of the araphid group is the most difficult because unlike the centric series their valve structure is rather simple, and unlike the raphid series, the plastids and their arrangements have few distinguishing features'. Thus, in spite of their

\footnotetext{
*Corresponding author (shinya.sato@awi.de).
}

high abundance, the defining features of the main groups of araphid diatoms are not fully established.

To obtain a more complete picture of the natural history of araphid diatoms, we have been collecting samples worldwide from coastal regions. Recently we encountered a new diatom that superficially resembled Striatella unipunctata (Lyngbye) Agardh. Scanning electron microscopy (SEM) revealed, however, that this diatom differed from S. unipunctata in several features that are generally used as taxonomic characters among araphid diatoms, including characteristics of the sternum, striae, areolae, apical pore field, rimoportula and septum. Given these observations, together with information on the plastids and 18S rDNA sequences, we conclude that the diatom should be described as a new genus, Pseudostriatella.

We have also been able to make detailed observations on the fine structure of auxospores produced spontaneously in monoclonal cultures. With the advent of electron microscopy, particularly SEM, information about auxospore structure has greatly increased (e.g. Crawford 1974; Mann 1982b; von Stosch 1982; Cohn et al. 1989; Kaczmarska et al. 2000, 2001; Kobayashi et al. 2001; Schmid \& Crawford 2001; Nagumo 2003; Sato et al. 2004, 2008a, b; Amato et al. 2005; Tiffany 2005; Toyoda et al. 2005, 2006; Trobajo et al. 
2006; Poulíčková \& Mann 2006; Poulíčková et al. 2007). However, although it has become clear that some aspects of the fine structure of auxospores have phylogenetic significance (e.g. Medlin \& Kazcmarska 2004), there is still insufficient information to reveal how the structure and development of auxospores have evolved in the major diatom groups, especially among the lineages of araphid pennate diatoms. Indeed, the only detailed information available concerning araphid pennates is the account of Rhabdonema Kützing by von Stosch $(1962,1982)$ and the SEM studies of Gephyria media Arnott (Sato et al. 2004), Grammatophora marina (Lyngbye) Kützing (Sato et al. 2008a) and Tabularia parva (Kützing) Williams \& Round (Sato et al. 2008b). In the present study, we compare the auxospore fine structure in these diatoms with that of Pseudostriatella oceanica and discuss the evolutionary relationships of Pseudostriatella.

\section{MATERIAL AND METHODS}

\section{Collections and cultures}

Both natural specimens and clonal cultures were examined in this study. Vegetative cells of the $P$. oceanica examined here were collected by S. Matsumoto at Yumigahama Beach, Minamiizu, Shizuoka Prefecture, Japan, on 20 May 2005, attached to Cladophora sp., and by B.K. Petkus at Horseneck State Beach, Westport, Massachusetts, USA, on August 2006, from bottom sand. For morphological comparison, $S$. unipunctata, the generitype of the genus Striatella, was collected by L.K. Medlin from Banyuls sur Mer, France, on 13 February 2005. Single cells were isolated from the American and French samples to obtain clonal cultures. Cultures were maintained in IMR medium (Eppley et al. 1967) at $15^{\circ} \mathrm{C}$ under cool-white fluorescent light on a $14: 10$-h (L : D) photoperiod at a photon flux density of $30-40 \mu \mathrm{mol}$ photons $\mathrm{m}^{-2} \mathrm{~s}^{-1}$. A coverslip was placed on the bottom of the culture vessel to be colonized with cells producing auxospores. Both strains examined in this study, $P$. oceanica s0384 and S. unipunctata s0208, are currently available on request to the first author but may not survive long-term in culture ( $c f$. Chepurnov et al. 2004).

\section{Microscopy}

An Axioplan (Zeiss) light microscope (LM) with bright field, differential interference contrast (DIC) or phase contrast optics was used to observe living cells and cleaned frustules. To photograph live specimens attached to the bottom of the culture vessel, a Zeiss Axiovert 35 inverted microscope was used, equipped with an AxioCam MRc digital camera. To remove organic material from the frustule, samples were treated as follows (modified from Nagumo \& Kobayashi 1990): (1) the sample was centrifuged to make a pellet and the supernatant discarded; (2) the pellet was resuspended in distilled water, and steps 1 and 2 were then repeated several times to remove salts; (3) to remove organic matter, the pellet was suspended (using a vortex mixer) in an equal volume of Drano Power-Gel (Johnson Wax), a strong domestic drain cleaner; (4) the suspension was left at room temperature for c. $30 \mathrm{~min}$; and (5) steps 1 and 2 were repeated several times to remove decomposition products. Cleaned frustules were then mounted in Mountmedia (refractive index $\mathrm{n} 20 / \mathrm{D}=1.50$; Wako).

For SEM examination, cleaned material was air-dried onto coverslips. To observe auxospores, coverslips to which the auxospore mother cells had already become attached were immersed in $10 \%$ glutaraldehyde for $1 \mathrm{~h}$ at room temperature, then washed with distilled water, air-dried and fixed to SEM stubs with carbon tape. For observations of cells still attached to the substratum by mucilaginous stalks, host plants were fixed with $10 \%$ glutaraldehyde for $2 \mathrm{~h}$ at $4^{\circ} \mathrm{C}$, rinsed with distilled water several times to remove the glutaraldehyde, dehydrated using increasing concentrations of t-butyl alcohol and freeze-dried using a JFD-310 instrument (JEOL). Freeze-dried specimens were attached to the stub directly with carbon tape. All SEM specimens were coated with gold using an SC 500 sputter coater (Emscope). A QUANTA 200F (FEI) was used for SEM observation at an accelerating voltage of $3-10 \mathrm{kV}$ and $c$. $10 \mathrm{~mm}$ working distance. All the images included in this paper are from cultured strains, except for those from freeze-dried material (Figs 9-13). Captured images were adjusted with Adobe Photoshop.

\section{DNA methods}

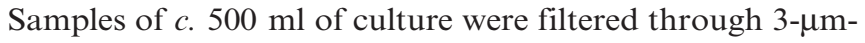
pore-diameter membrane filters (Millipore). Filters were immersed in $500 \mu \mathrm{l}$ DNA extraction buffer containing $2 \%$ (w/v) CTAB, $1.4 \mathrm{M} \mathrm{NaCl}, 20 \mathrm{mM}$ EDTA, $100 \mathrm{mM}$ Tris$\mathrm{HCl}, \mathrm{pH} 8,0.2 \%$ (w/v) PVP, $0.01 \%$ (w/v) SDS and $0.2 \% \beta-$ mercaptoethanol. Immersed filters were incubated at $65^{\circ} \mathrm{C}$ for $5 \mathrm{~min}$, vortexed for a few seconds and then discarded. Subsequently, the buffer was cooled briefly on ice. DNA was extracted with an equal volume of chloroform-isoamyl alcohol (24:1 [v/v]) and centrifuged in a tabletop Eppendorf microfuge (Eppendorf) at maximum speed $(14,000 \mathrm{rpm})$ for $10 \mathrm{~min}$. The aqueous phase was collected, re-extracted with chloroform-isoamyl alcohol and centrifuged as described previously. Next, the aqueous phase was mixed thoroughly with 0.8 volumes of ice-cold $100 \%$ isopropanol, left on ice for $5 \mathrm{~min}$ and subsequently centrifuged in a precooled Eppendorf microfuge at maximum speed for $15 \mathrm{~min}$. DNA pellets were washed in $500 \mu 170 \%(\mathrm{v} / \mathrm{v})$ ethanol, centrifuged for $6 \mathrm{~min}$ and then allowed to air-dry after decanting off the ethanol. DNA pellets were dissolved overnight in $100 \mu \mathrm{l}$ water. The quantity and quality of DNA were examined by agarose gel electrophoresis against known standards.

The targeted marker sequence comprised the $18 \mathrm{~S}$ rDNA within the nuclear rDNA cistron. The marker was PCRamplified in $25-\mu 1$ volumes containing $10 \mathrm{ng}$ DNA, $1 \mathrm{mM}$ dNTPs, $0.5 \mu \mathrm{M}$ of forward primer, $0.5 \mu \mathrm{M}$ of reverse primer, $1 \times$ Roche diagnostics PCR reaction buffer (Roche Diagnostics) and 1 unit Taq DNA polymerase (Roche). The PCR cycling comprised an initial 4-min heating step at $94^{\circ} \mathrm{C}$, followed by 35 cycles of $94^{\circ} \mathrm{C}$ for $2 \mathrm{~min}, 56^{\circ} \mathrm{C}$ for $4 \mathrm{~min}$ and $72^{\circ} \mathrm{C}$ for $2 \mathrm{~min}$ and a final extension at $72^{\circ} \mathrm{C}$ for $10 \mathrm{~min}$. PCR products were generated using the forward primer A and a reverse primer B (Medlin et al. 1988) 
without the polylinkers. The quantity and length of products were examined by agarose gel electrophoresis against known standards. Excess primers and dNTPs were removed from PCR product using the QIAQuick purification kit (QIAGEN), following the manufacturer's instructions. The cleaned PCR products were then electrophoresed on an ABI 3100 Avant sequencer (Applied Biosystems) using Big Dye Terminator v. 3.1 sequencing chemistry (Applied Biosystems) with the sequencing primers specified by Elwood et al. (1985).

\section{Data analyses}

The obtained 18S rDNA sequences were aligned with publicly available sequences retrieved from GenBank (Table 1), first using ClustalX (Thompson et al. 1997) and then refined by referring to the secondary structure model of the 18S rRNA at the database of the structure of rRNA (Van de Peer et al. 1998). There is extreme length variation in some rRNAs (e.g. Gillespie et al. 2005), and replication slippage often leads to convergence on similar primary and secondary structures (Hancock \& Vogler 2000; Shull et al. 2001). Homology assessment in such regions was difficult or impossible, so that the highly variable regions (most peripheral regions of the 18S rRNA secondary structure) were removed from the alignment using BioEdit 7.0.2 (Hall 1999) by referring to the variability map of Saccharomyces cerevisiae (Van de Peer et al. 1993), resulting in 1713 nucleotides in the data set.

The data set consisted of 181 OTUs including the closest relatives of the diatoms Bolidomonas mediterranea Guillou \& Chrétiennot-Dinet and B. pacifica Guillou \& Chrétiennot-Dinet (Guillou et al. 1999) as outgroups. The alignment examined in this study is available at TreeBASE (SN3793).

To determine which model of sequence evolution best fits the data, hierarchical likelihood ratio tests and the Akaike information criterion were performed using Modeltest 3.7 (Posada \& Crandall 1998), and both tests selected the GTR $+\mathrm{I}+\mathrm{G}$ model. This model had the following parameters: base frequencies $=\mathrm{A}: 0.2685, \mathrm{C}: 0.1643, \mathrm{G}: 0.2539$ and $\mathrm{T}$ : 0.3133 ; substitution rates were $\mathrm{A}-\mathrm{C}=1.2232, \mathrm{~A}-\mathrm{G}=$ $3.1535, \mathrm{~A}-\mathrm{T}=1.2675, \mathrm{C}-\mathrm{G}=1.4955, \mathrm{C}-\mathrm{T}=5.5072$ and $\mathrm{G}-\mathrm{T}=1.0000$; the proportion of invariant sites was 0.2825 ; and among-site rate heterogeneity was described by a gamma distribution with a shape parameter of 0.6058 . Phylogenies were reconstructed with PAUP v. $4.0 \mathrm{~b} 10$ (Swofford 2002) using neighbour joining (NJ) of likewiseconstrained pairwise maximum likelihood (ML) distances. Nodal support was estimated using NJ bootstrap analyses using the same settings (1000 replicates).

Maximum parsimony (MP) tree searches were done with the 'new technology' search algorithm implemented in the Willi Hennig Society edition of TNT 1.1 (http://www.zmuc. $\mathrm{dk} /$ public/phylogeny/TNT). One hundred random addition sequence replicates were performed with default values. Nonparametric bootstrap analyses were done 1000 times with the 'traditional' search algorithm in TNT.

Maximum likeli hood analyses were performed by RAxML-VI-HPC, v. 2.2.3 (Stamatakis et al. 2005) with the GTRMIX model. The analyses were performed 100 times to find the best topology receiving the best likelihood using different random starting MP trees (one round of taxon addition) and the rapid hill-climbing algorithm (i.e. option - $\mathrm{f} d$ in RAxML). Bootstrap values were obtained by 100 replications with the GTRCAT model.

The Message Passing Interface (MPI) version of MrBayes 3.1.2 (Huelsenbeck \& Ronquist 2001; Ronquist \& Huelsenbeck 2003; Altekar et al. 2004) was used for Bayesian analyses with the GTR $+\mathrm{I}+\mathrm{G}$ model to estimate the posterior probability distribution using MetropolisCoupled Markov chain Monte Carlo (MCMCMC) (Ronquist \& Huelsenbeck 2003). The MCMCMC from a random starting tree was used in this analysis with two independent runs and one cold and three heated chains. The Bayesian analyses were run for 20 million generations each with trees sampled every 100th generation. To increase the probability of chain convergence, we sampled trees after the standard deviation values of the two runs dipped below 0.01 to calculate the posterior probabilities (i.e. after $8,300,000$ generations). The remaining phylogenies were discarded as burn-in.

\section{Terminology}

Terminology follows Anonymous (1975) and (particularly for auxospore structures) Round et al. (1990). Molecular phylogenetic studies of diatoms have revealed that historical diatom classifications do not reflect a natural system and that araphid pennate diatoms are paraphyletic in most gene phylogenies, for example, using nuclear $18 \mathrm{~S}$ ribosomal DNA (rDNA) and plastid 16S rDNA (Medlin \& Kaczmarska 2004). Nevertheless, we use the terms araphid and centric here because they refer to key morphological features or their absence. In this paper, the term araphid pennate diatom follows the traditional definition, that is, a diatom that has an elongate valve with a central or slightly lateral sternum, apical pore fields and often also apical rimoportulae but that lacks a raphe slit. We do not imply that this corresponds to a mono- (holo-) phyletic group or that it should be accorded any taxonomic status.

\section{RESULTS}

\section{Pseudostriatella S. Sato, Mann \& Medlin gen. nov.}

\section{Figs 1-53}

Cellulae rectangulares in aspectu cincturae angulis rotundatis, angulo unico per stipitem muci ad substratum adhaerentes. Chloroplasti c. 10 dispersi et cellulam complentes. Taeniae cincturae numerosae apertae septo conspicuo poros aliquot praebenti. Valvae lanceolatae, ocello ad utrumque polum, fronte in sectione transversali arcuata, sine limbo distincto. Striae irregulares in LM non manifestae. Sternum typicum nullum sed area hyalina secus axem longam adest. Areolae per clavulas occlusae, igitur aperturis dendriticis instructae. Rimoportulae multae dispersae, forma interna variabili.

Cells attached to the substratum by a mucilage stalk at one corner of the frustule, rectangular in girdle view, with rounded corners. Plastids $c$. 10 per cell, scattered and filling the cell. Copulae numerous open hoops, each with a conspicuous septum containing several pores. Valve lanceolate, with an apical pore field (ocellus) at each pole. Valve face arched, without a distinct mantle. Striae irregular, unresolved with LM. Sternum apparently absent, but a 
Table 1. List of taxon and GenBank accession numbers for $18 \mathrm{~S}$ rDNA sequences used in this study.

\begin{tabular}{|c|c|}
\hline Taxon & $\begin{array}{l}\text { Accession } \\
\text { no. }\end{array}$ \\
\hline Aulacoseira ambigua (Grunow) Simonsen & X85404 \\
\hline Aulacoseira baicalensis (Meyer) Simonsen & AJ535185 \\
\hline Aulacoseira baicalensis (Meyer) Simonsen & AJ535186 \\
\hline Aulacoseira baicalensis (Meyer) Simonsen & AY121821 \\
\hline Aulacoseira distans (Ehrenberg) Simonsen & X85403 \\
\hline Aulacoseira islandica (Müller) Simonsen & AJ535183 \\
\hline Aulacoseira islandica (Müller) Simonsen & AY 121820 \\
\hline Aulacoseira nyassensis (Müller) Simonsen & AJ535187 \\
\hline Aulacoseira nyassensis (Müller) Simonsen & AY121819 \\
\hline Aulacoseira skvortzowii Edlund, Stoermer et Taylor & AJ535184 \\
\hline Aulacoseira subarctica (Müller) Haworth & AY121818 \\
\hline Actinocyclus curvatulus Janisch & X85401 \\
\hline Actinoptychus seniarius (Ehrenberg) Héribaud & AJ535182 \\
\hline Bellerochea malleus (Brightwell) van Heurck & AF525671 \\
\hline $\begin{array}{l}\text { Biddulphiopsis titiana (Grunow) von Stosch et } \\
\text { Simonsen }\end{array}$ & AF525669 \\
\hline Chaetoceros curvisetus Cleve & AY229895 \\
\hline Chaetoceros debilis Cleve & AY229896 \\
\hline Chaetoceros didymus Ehrenberg & X85392 \\
\hline Chaetoceros gracilis Schütt & AY229897 \\
\hline Chaetoceros rostratus Lauder & X85391 \\
\hline Chaetoceros sp. & AF145226 \\
\hline Chaetoceros sp. & AJ535167 \\
\hline Chaetoceros sp. & X85390 \\
\hline Corethron criophilum Castracane & X85400 \\
\hline Corethron inerme Karsten & AJ535180 \\
\hline Corethron hystrix Hensen & AJ535179 \\
\hline Coscinodiscus radiatus Ehrenberg & X77705 \\
\hline Cyclotella meneghiniana Kützing & AJ535172 \\
\hline Cyclotella meneghiniana Kützing & AY496206 \\
\hline Cyclotella meneghiniana Kützing & AY496207 \\
\hline Cyclotella meneghiniana Kützing & AY496210 \\
\hline Cyclotella meneghiniana Kützing & AY496212 \\
\hline Cyclotella cf. scaldensis & AY496208 \\
\hline Cymatosira belgica Grunow & X85387 \\
\hline Detonula confervacea (Cleve) Gran & AF525672 \\
\hline Ditylum brightwellii (West) Grunow in Van Heurck & AY 188181 \\
\hline Ditylum brightwellii (West) Grunow in Van Heurck & AY 188182 \\
\hline Ditylum brightwellii (West) Grunow in Van Heurck & X85386 \\
\hline Eucampia antarctica (Castracane) Mangin & X85389 \\
\hline Guinardia delicatula (Cleve) Hasle & AJ535192 \\
\hline Guinardia flaccida (Castracane) H. Peragallo & AJ535191 \\
\hline Helicotheca tamesis (Schrubsole) Ricard & X85385 \\
\hline Lampriscus kittonii Schmidt & AF525667 \\
\hline Lauderia borealis Cleve & X85399 \\
\hline Leptocylindrus danicus Cleve & AJ535175 \\
\hline Leptocylindrus minimus Gran & AJ535176 \\
\hline Lithodesmium undulatum Ehrenberg & Y10569 \\
\hline Melosira varians Agardh & AJ243065 \\
\hline Melosira varians Agardh & X85402 \\
\hline Odontella sinensis (Greville) Grunow & Y10570 \\
\hline Papiliocellulus elegans Hasle, von Stosch et Syvertsen & X85388 \\
\hline Paralia sol (Ehrenberg) Crawford & AJ535174 \\
\hline Planktoniella sol (Wallich) Schütt & AJ535173 \\
\hline Pleurosira laevis (Ehrenberg) Comperé & AF525670 \\
\hline Porosira pseudodenticulata (Hustedt) Jousé & X85398 \\
\hline Proboscia alata (Brightwell) Sundström & AJ535181 \\
\hline Rhizosolenia imbricate Brightwell & AJ535178 \\
\hline Rhizosolenia similoides Cleve-Euler & J535177 \\
\hline Rhizosolenia setigera Brightwell & M87329 \\
\hline Skeletonema costatum (Greville) Cleve & X52006 \\
\hline Skeletonema costatum (Greville) Cleve & X85395 \\
\hline Skeletonema menzelii Guillard, Carpenter & AJ535168 \\
\hline Skeletonema menzelii Guillard, Carpenter et Reimer & AJ536450 \\
\hline Skeletonema pseudocostatum Medlin & AF462060 \\
\hline Skeletonema pseudocostatum Medlin & X85393 \\
\hline Skeletonema subsalsum (Cleve-Euler) Bethge & AJ535166 \\
\hline Skeletonema sp. & AJ535165 \\
\hline
\end{tabular}

Table 1. Continued

\begin{tabular}{|c|c|}
\hline Taxon & $\begin{array}{l}\text { Accession } \\
\text { no. }\end{array}$ \\
\hline Stephanopyxis cf. broschii & M87330 \\
\hline Thalassiosira eccentrica (Ehrenberg) Cleve & X85396 \\
\hline Thalassiosira guillardii Hasle & AF374478 \\
\hline Thalassiosira oceanica Hasle & AF374479 \\
\hline Thalassiosira pseudonana Hasle et Heimdal & AJ535169 \\
\hline Thalassiosira pseudonana Hasle et Heimdal & AF374481 \\
\hline Thalassiosira rotula Meunier & AF374480 \\
\hline Thalassiosira rotula Meunier & AF462058 \\
\hline Thalassiosira rotula Meunier & AF462059 \\
\hline Thalassiosira rotula Meunier & X85397 \\
\hline Thalassiosira weissflogii (Grunow) Fryxell et Hasle & AF374477 \\
\hline Thalassiosira weissflogii (Grunow) Fryxell et Hasle & AJ535170 \\
\hline Thalassiosira sp. & AJ535171 \\
\hline Toxarium undulatum Bailey & AF525668 \\
\hline Asterionella formosa Hassall & AF525657 \\
\hline Asterionellopsis glacialis (Castracane) Round & X77701 \\
\hline Asterionellopsis glacialis (Castracane) Round & AY216904 \\
\hline \multicolumn{2}{|c|}{ Asteroplanus karianus ${ }^{1}$ (Grunow in Cleve et Grunow) } \\
\hline Gardner et Crawford & Y10568 \\
\hline Cyclophora tenuis Castracane & AJ535142 \\
\hline Diatoma hyemalis (Roth) Heiberg & AB085829 \\
\hline Diatoma tenue Agardh & AJ535143 \\
\hline Fragilaria crotonensis Kitton & AF525662 \\
\hline Fragilariforma virescens (Ralfs) Williams et Round & AJ535137 \\
\hline Grammatophora gibberula Kützing & AF525656 \\
\hline Grammatophora oceanica Ehrenberg & AF525655 \\
\hline Grammatophora marina (Lyngbye) Kützing & AY216906 \\
\hline Grammonema striatula Agardh ${ }^{1}$ & X77704 \\
\hline Grammonema cf. islandica ${ }^{1}$ & AJ535190 \\
\hline Grammonema sp. $^{1}$ & AJ535141 \\
\hline Hyalosira delicatula Kützing & AF525654 \\
\hline Licmophora juergensii Agardh & AF525661 \\
\hline \multirow{2}{*}{\multicolumn{2}{|c|}{ Nanofrustulum shiloi (Lee, Reimer et McEnery) Round, }} \\
\hline & \\
\hline Pseudostriatella oceanica S. Sato, Mann et Medlin & AB379680 \\
\hline Rhabdonema arcuatum (Agardh) Kützing & AF525660 \\
\hline \multicolumn{2}{|l|}{ Rhaphoneis cf. belgica (Grunow in van Heurck) } \\
\hline Grunow in van Heurck & X77703 \\
\hline Staurosira construens Ehrenberg & AF525659 \\
\hline Striatella unipunctata (Lyngbye) Agardh & AF525666 \\
\hline Synedra $\mathrm{sp.}^{2}$ & AJ535138 \\
\hline Tabularia tabulata (Agardh) Williams et Round & AY216907 \\
\hline Talaroneis posidoniae Kooistra et De Stefano & AY216905 \\
\hline Thalassionema nitzschioides (Grunow) Hustedt & X77702 \\
\hline Thalassionema sp. & AJ535140 \\
\hline Synedra ulna Nitzsch & AJ535139 \\
\hline Achnanthes bongrainii (M. Peragallo) A. Mann & AJ535150 \\
\hline Achnanthes sp. & AJ535151 \\
\hline Amphora montana Krasske & AJ243061 \\
\hline Amphora cf. capitellata & AJ535158 \\
\hline Amphora cf. proteus & AJ535147 \\
\hline Anomoeoneis sphaerophora (Ehrenberg) Pfitzer & AJ535153 \\
\hline Bacillaria paxillifer (Müller) Hendey & M87325 \\
\hline Campylodiscus ralfsii Gregory & AJ535162 \\
\hline Cocconeis cf. molesta & AJ535148 \\
\hline $\begin{array}{l}\text { Cylindrotheca closterium (Ehrenberg) Reimann et } \\
\text { Lewin }\end{array}$ & M87326 \\
\hline Cymbella cymbiformis Agardh & AJ535156 \\
\hline Encyonema triangulatum Kützing & AJ535157 \\
\hline Entomoneis cf. alata & AJ535160 \\
\hline Eolimna minima (Grunow) Lange-Bertalot & AJ243063 \\
\hline Eolimna subminuscula (Manguin) Moser, Lange- & \\
\hline Bertalot et Metzeltin & AJ243064 \\
\hline Eunotia formica var. sumatrana Hustedt & AB085830 \\
\hline Eunotia monodon var. asiatica Skvortzow & AB085831 \\
\hline Eunotia pectinalis (Dillwyn) Rabenhorst & AB085832 \\
\hline Eunotia $\mathrm{cf}$. pectinalis $\mathrm{f}$. minor & AJ535146 \\
\hline Eunotia sp. & AJ535145 \\
\hline Fragilariopsis sublineata Hasle & AF525665 \\
\hline
\end{tabular}


Table 1. Continued

\begin{tabular}{|c|c|}
\hline Taxon & $\begin{array}{c}\text { Accession } \\
\text { no. }\end{array}$ \\
\hline Gomphonema parvulum Kützing & AJ243062 \\
\hline Gomphonema pseudoaugur Lange-Bertalot & AB085833 \\
\hline Lyrella atlantica (Schmidt) D. G. Mann & AJ544659 \\
\hline Navicula cryptocephala var. veneta (Kützing) Grunow & AJ297724 \\
\hline Navicula diserta Hustedt & AJ535159 \\
\hline Navicula pelliculosa (Brébisson ex Kützing) Hilse & AJ544657 \\
\hline Nitzschia apiculata (Gregory) Grunow & M87334 \\
\hline Nitzschia frustulum (Kützing) Grunow & AJ535164 \\
\hline Pinnularia cf. interrupta & AJ544658 \\
\hline Pinnularia sp. & AJ535154 \\
\hline Phaeodactylum tricornutum Bohlin & AJ269501 \\
\hline \multicolumn{2}{|l|}{ Planothidium lanceolatum (Brébisson ex Kützing) } \\
\hline Round et Bukhtiyarova & AJ535189 \\
\hline Pleurosigma sp. & AF525664 \\
\hline Pseudogomphonema sp. & AF525663 \\
\hline Pseudogomphonema sp. & AJ535152 \\
\hline Pseudo-nitzschia multiseries (Hasle) Hasle & U18241 \\
\hline Pseudo-nitzschia pungens (Grunow ex Cleve) Hasle & U18240 \\
\hline Rossia sp. & AJ535144 \\
\hline Sellaphora capitata Mann et McDonald & AJ535155 \\
\hline Sellaphora pupula (Kützing) Mereschkowsky & AJ544645 \\
\hline Sellaphora pupula (Kützing) Mereschkowsky & AJ544651 \\
\hline Sellaphora pupula (Kützing) Mereschkowsky & AJ544647 \\
\hline Sellaphora pupula (Kützing) Mereschkowsky & AJ544648 \\
\hline Sellaphora pupula (Kützing) Mereschkowsky & AJ544649 \\
\hline Sellaphora pupula (Kützing) Mereschkowsky & AJ544650 \\
\hline Sellaphora pupula (Kützing) Mereschkowsky & AJ544652 \\
\hline Sellaphora pupula (Kützing) Mereschkowsky & AJ544653 \\
\hline Sellaphora pupula (Kützing) Mereschkowsky & AJ544654 \\
\hline Sellaphora laevissima (Kützing) D. G. Mann & AJ544655 \\
\hline Sellaphora laevissima (Kützing) D. G. Mann & AJ544656 \\
\hline \multicolumn{2}{|l|}{ Surirella fastuosa var. cuneata (Schmidt) } \\
\hline H. Peragallo et M. Peragallo & AJ535161 \\
\hline Thalassiosira antarctica Comber & AF374482 \\
\hline \multirow{2}{*}{\multicolumn{2}{|c|}{ Bolidomonas mediterranea Guillou et }} \\
\hline & \\
\hline Chretéinnot-Di & AF123596 \\
\hline Bolidomonas pacifica Guillou et Chréteinnot-Dinet & AF123595 \\
\hline Bolidomonas pacifica Guillou et Chréteinnot-Dinet & AF167153 \\
\hline Bolidomonas pacifica Guillou et Chréteinnot-Dinet & AF 167154 \\
\hline Bolidomonas pacifica Guillou et Chréteinnot-Dinet & AF167155 \\
\hline Bolidomonas pacifica Guillou et Chréteinnot-Dinet & AF 167156 \\
\hline Bolidomonas pacifica Guillou et Chréteinnot-Dinet & AF167157 \\
\hline Convoluta convoluta diatom endosymbiont & AY345013 \\
\hline Peridinium foliaceum endosymbiont & Y10567 \\
\hline Peridinium balticum endosymbiont & Y10566 \\
\hline Uncultured diatom & AY180014 \\
\hline Uncultured diatom & AY180015 \\
\hline Uncultured diatom & AY180016 \\
\hline Uncultured diatom & AY 180020 \\
\hline Uncultured eukaryote & AY082977 \\
\hline Uncultured eukaryote & AY082992 \\
\hline Uncultured marine diatom & AF290085 \\
\hline
\end{tabular}

\footnotetext{
${ }^{1}$ Name change since deposit.

${ }^{2}$ Likely a new genus collected from a marine habitat (Medlin et al. 2008a).
}

hyaline area is present along the long axis. Areolae occluded by peg-like structures and therefore with dendritic apertures. Many rimoportulae present, of variable form internally.

TYPE SPECIES: P. oceanica S. Sato, Mann \& Medlin sp. nov. Descriptio speciei eadem est ac descriptio generis; valvae 16.0$47.8 \mu \mathrm{m}$ longae, $4.4-5.3 \mu \mathrm{m}$ latae.

HOLOTYPE: BRM Zu6/38.
ISOTYPE: TNS-AL-53995.

TYPE LOCALITY: Horseneck State Beach, Westport, MA, USA.

DISTRIBUTION: Known only from the type locality and Yumigahama Beach, Minamiizu, Shizuoka Prefecture, Japan.

\section{Morphology of vegetative cells}

In the culture vessel, cells of $P$. oceanica attached to the bottom, usually by means of a mucilaginous stalk secreted from one corner, which reached a maximum length of $c$. $20 \mu \mathrm{m}$ (Fig. 1). Cells occasionally attached to each other to make zigzag chains (not shown), but this was seen only in culture, and chains of over five cells were never found. About 10 lobed plastids were scattered through the cell (Fig. 2). A prominent body, likely a pyrenoid, was often visible at the centre of a plastid (Fig. 2, arrow). In girdle view, when the focus was on the surface of the cell, longitudinal rib-like thickenings were visible on some of the girdle bands (Fig. 3). Spots could sometimes be seen on the valve mantle (e.g. at arrow, Fig. 3), and tiny projections were sometimes visible extending inwards from the valve face (e.g. at the centre of the valve in Fig. 4); these features probably represent rimoportulae (see below).

The valves were lanceolate with acute ends (Figs 5, 6). No striae could be resolved in LM with bright field (Fig. 5), DIC (Fig. 6) or phase contrast optics (not shown). The valve length was $16.0-47.8 \mu \mathrm{m}$. Auxospore mother cells measured $16.9 \pm 0.6 \mu \mathrm{m}$ (mean $\pm s, n=8$ ), and initial cells were $41.1 \pm 3.1 \mu \mathrm{m}(n=12)$. The valve width was 4.4 $5.3 \mu \mathrm{m}$. Apical pore fields were recognisable in LM as hyaline areas at both ends of a valve (Figs 5, 6).

The frustule had numerous girdle bands (c. 10 per theca: Figs 8, 10), each being an incomplete hoop, open at one end (Fig. 7). The closed end of each band bore a septum, which extended inwards by one-sixth to one-eighth of the valve length (Figs 4, 7). The alternation of the septa (Figs 8, 12, 32) gave a Striatella-like appearance to the cell in girdle view (Fig. 3).

Observations of freeze-dried specimens from field material revealed that the surface of the host plant was covered with bacteria (Figs 9, 10, 13). The long mucilaginous stalk (Fig. 9) was secreted from one of the apical pore fields (Fig. 11), but no secretion occurred from other (Fig. 12). The thickness of the stalk was c. $1 \mu \mathrm{m}$ (Figs 9, 10, 13). The surface of the mucilaginous stalk was not uniform but comprised many fine strings and thus appeared fibrous (Fig. 13).

The valve face was smoothly rounded (Fig. 14), lacking an abrupt change between it and the mantle. The areolae were irregularly scattered over some parts of the valve, especially towards the poles, but formed parallel striae towards the centre and radiating striae elsewhere (Fig. 14). A clearly defined sternum was absent, but there was an irregular hyaline area along the long axis of the valve (Fig. 14). This hyaline area (1) did not occupy the whole but at most only about one-half of the long axis of the valve (Fig. 14), (2) was wider at both ends than in the centre (Fig. 14), and (3) was perforated by small pores in the two wide end sections (Fig. 15). Apical pore fields were present 

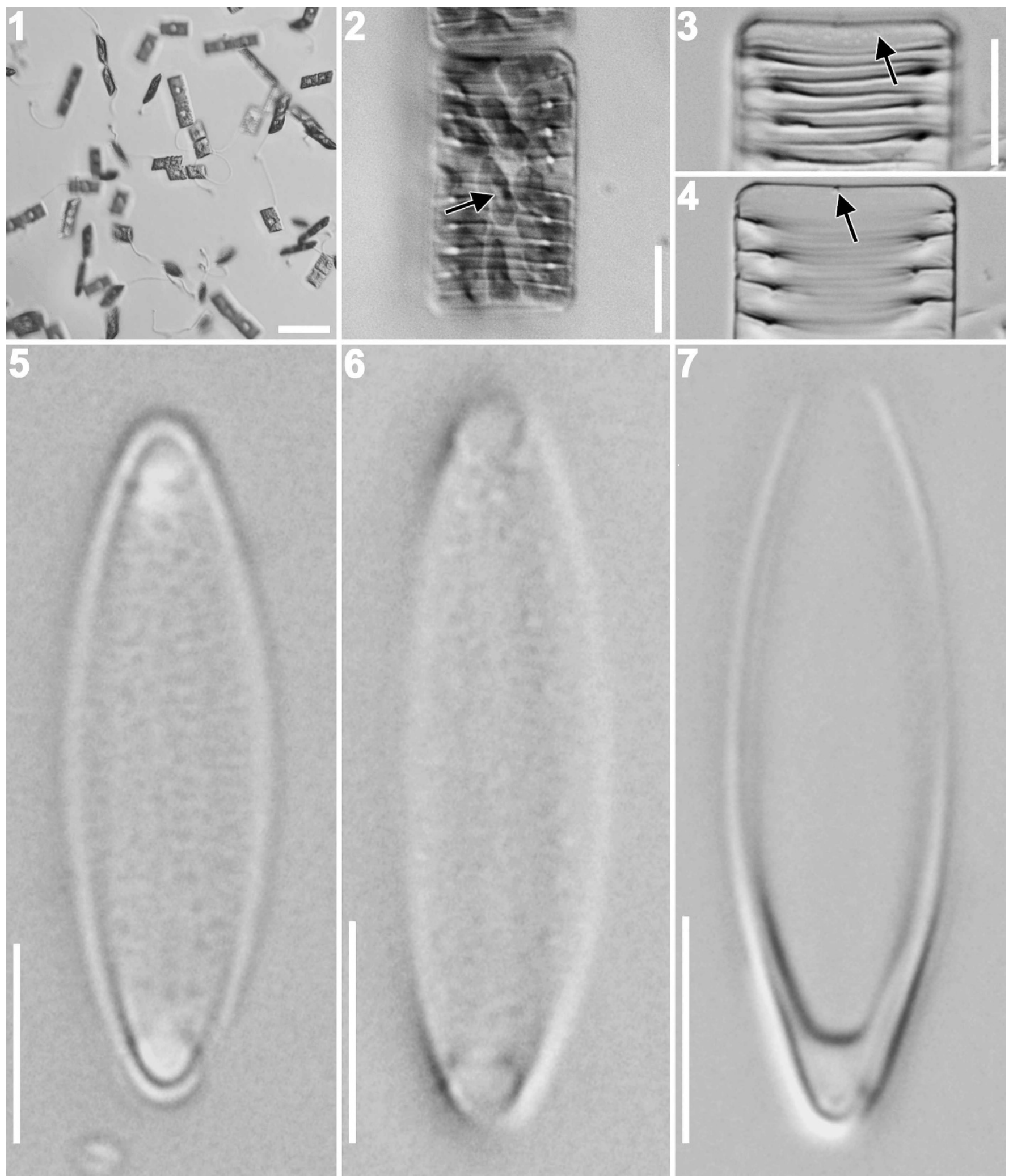

Figs 1-7. Pseudostriatella oceanica: living and cleaned cells (LM). Scale bars $=100 \mu \mathrm{m}$ (Fig. 1), $10 \mu \mathrm{m}$ (Figs 2,3$)$ or $5 \mu \mathrm{m}$ (Figs $5-7)$. Fig. 1. Living cells growing in culture vessel.

Fig. 2. Living cell showing multiple plastids. Arrow indicates presumable pyrenoid.

Fig. 3. Cleaned frustule, focused on surface to show prominent ribs along the girdle bands, continuous with the septa. The arrow indicates a white spot on the valve that is probably a rimoportula.

Fig. 4. Median focus of the frustule in Fig. 3, showing septate girdle bands; arrow indicates probable rimoportula.

Fig. 5. Cleaned valve (bright field).

Fig. 6. Cleaned valve (DIC).

Fig. 7. Single girdle band with septum at closed end. 

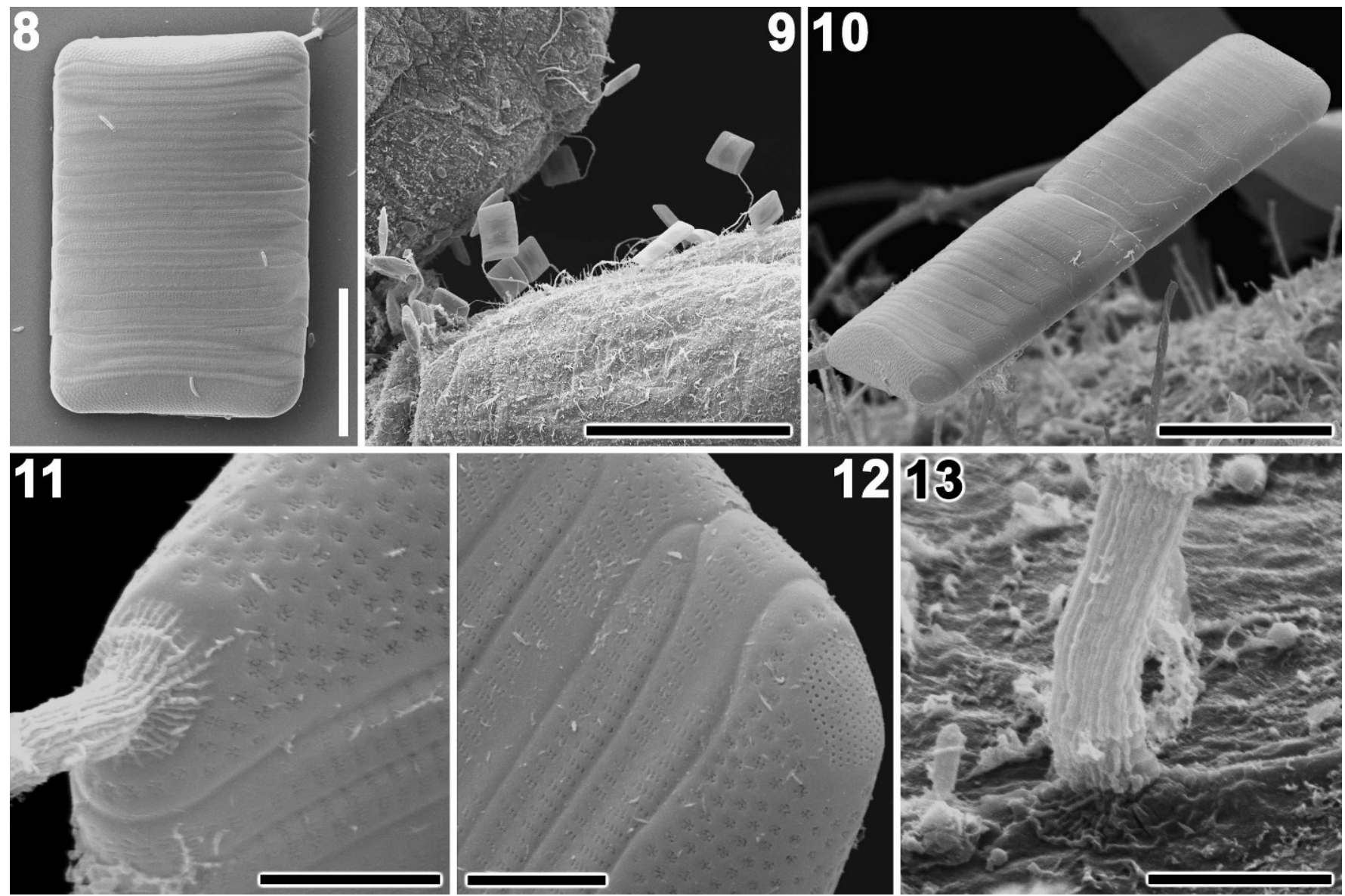

Figs 8-13. Pseudostriatella oceanica; intact cells, SEM. Scale bars $=10 \mu \mathrm{m}$ (Figs 8, 10), $100 \mu \mathrm{m}$ (Fig. 9) or $2 \mu \mathrm{m}$ (Figs 11-13).

Fig. 8. Frustule with mucilage stalk secreted at upper right corner.

Fig. 9. Colonies on Cladophora sp. Note the cells raised above bacterial community on algal surface by long mucilage stalks.

Fig. 10. Side view of frustules just after cell division.

Fig. 11. Mucilage stalk secreted from apical pore field.

Fig. 12. Free end of valve showing apical pore field secreting no mucilage.

Fig. 13. Mucilage stalk attachment to substratum. Note stalk is composed of fine mucilaginous strings.

at both ends of the valve. They had slightly thickened rims and contained small round pores in a strict hexagonal array (Fig. 16). This structure conforms to the definition of an ocellus (Ross et al. 1979). The areolae were more or less isodiametric, and each was occluded by two to several pegs leaving a dendritic aperture (Figs 17, 18).

On the inner surface of the valve, the hyaline area was less obvious than on the exterior but still recognizable (Fig. 19). The peg-like occlusions of the areolae were slightly sunk below the surface internally (Fig. 22), suggesting that these structures were external developments (contrast Figs 17, 18). A few of the pores within the widened ends of the hyaline area penetrated the valve (Fig. 20). The ocelli were not rimmed internally (Fig. 21), in contrast to the external appearance (Fig. 16). Approximately 15-30 rimoportulae were found scattered around the edge of each valve (Figs 19, 23, 24), all of them having a similar size but varying in shape (Figs 25-28). The most common form was 'C-shaped', the lips of the process being continuous on one side. This type of process could be either circular (Fig. 25) or elliptical (Fig. 26). Processes with two entire labiate slits (Fig. 27) were also commonly seen. This bilabiate process is not the same as the bilabiate process in the Lithodesmiales. Rarely, fused processes were observed (Fig. 28). The basal part of each rimoportula always overlapped part of an areola (Figs 25-28). Externally, the openings of the rimoportulae were undetectable (Figs 14 18).

The closed end of each girdle band bore a septum (Fig. 29), which was irregularly perforated by many scattered pores of variable size (Figs 29-31). The pars exterior was perforated by simple slit-like areolae arranged in short striae (Fig. 32); its margins were plain (Fig. 32, arrow and arrowhead, respectively). The closed end of the band was widened in the pervalvar direction to form a ligula (pointing towards the valve) and a smaller antiligula (pointing away from the valve), which were also perforated (Fig. 33). Towards the open ends of the band, the septum became shallower, finally becoming a simple interstria (Fig. 33). The girdle band areolae were slightly sunken internally (Figs 33, 34).

\section{Auxospore structure}

Auxosporulation occurred spontaneously in the clonal culture. Nuclear behaviour was not observed in this study, 

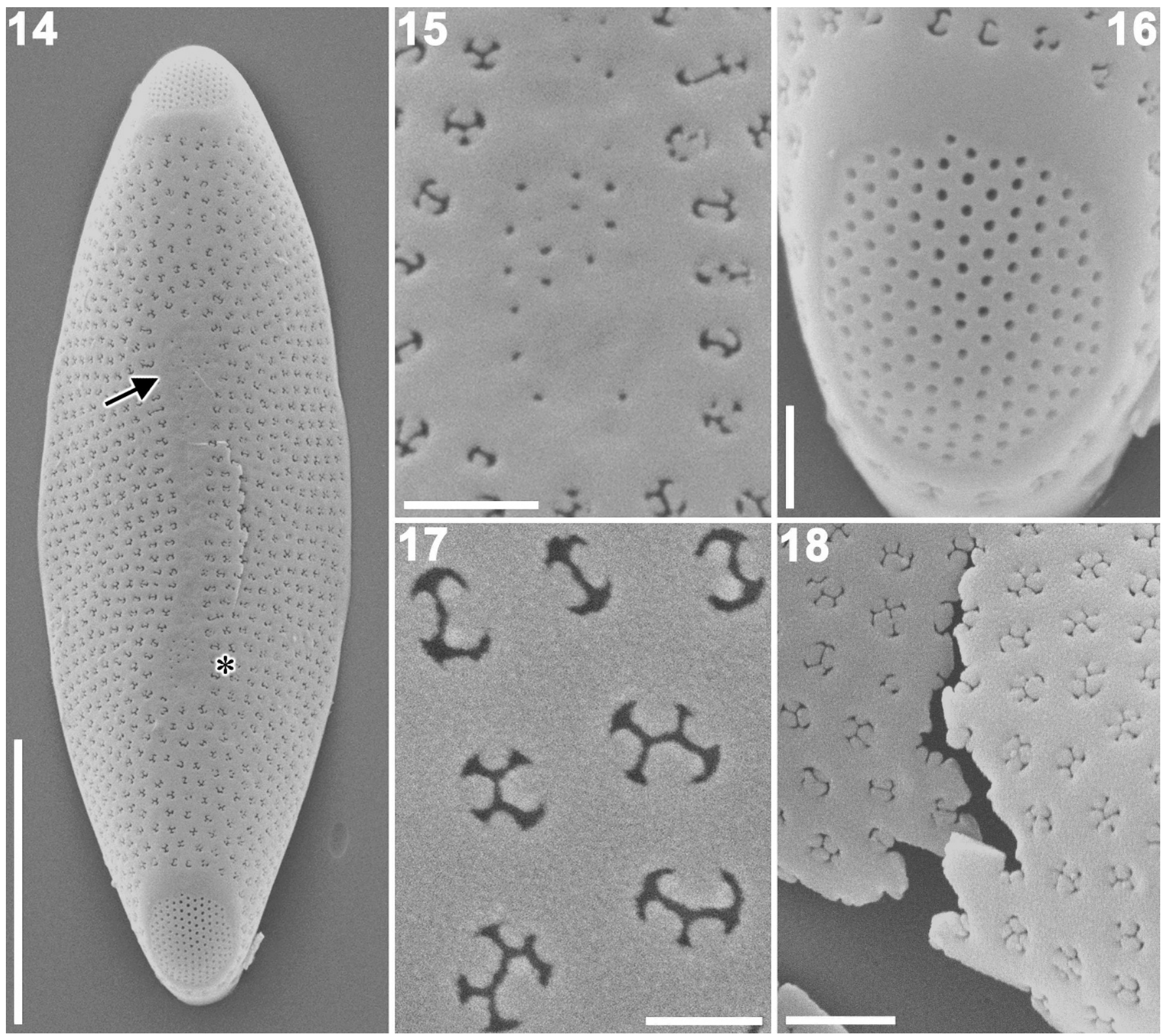

Figs 14-18. Pseudostriatella oceanica valves: external views (SEM). Scale bars $=5 \mu \mathrm{m}$ (Fig. 14), $0.5 \mu \mathrm{m}$ (Figs $15,16,18)$ or $0.2 \mu \mathrm{m}$ (Fig. 17).

Fig. 14. Whole showing central hyaline area (arrow) and irregular striation.

Fig. 15. Enlarged view of part marked by asterisk in Fig. 14 showing small simple pores within the end of the hyaline area.

Fig. 16. Detail of apical pore field surrounded by plain rim.

Fig. 17. Areolae occluded by pegs that vary in shape and number.

Fig. 18. Broken valve showing simple nonchambered valve structure.

and the earliest stages directly observed were the dehiscence of the auxospore mother cell, the liberation of the protoplast from its frustule and its bodily movement to a position beyond the open end of one vacated theca (Figs 35-37). The auxospore maintained this position subsequently (Figs 37, 38) and must have been physically connected to the empty mother-cell wall, presumably by mucilage, but the exact nature of the connection could not be established. The young auxospore was more or less spherical (Fig. 37). It then expanded at right angles to the pervalvar axis of the gametangium and parallel to its longitudinal axis (Fig. 38). No perizonial caps were observed at any stage of auxosporulation. All mother cells observed in this study were associated with only a single auxospore (Figs 35-38).

In the earliest stage observed by SEM (Fig. 39), the organic spherical auxospore did not seem to be covered with a mucilage layer or with any siliceous structures. Slightly expanded auxospores (Fig. 40), however, were bordered by a plain fringe of material, which probably represented a delicate mucilaginous envelope (Fig. 41). In auxospores that had already expanded significantly (Figs 42, 43), a striated siliceous structure (Fig. 43) could be seen within the mucilaginous layer (Fig. 43), and this can probably be 


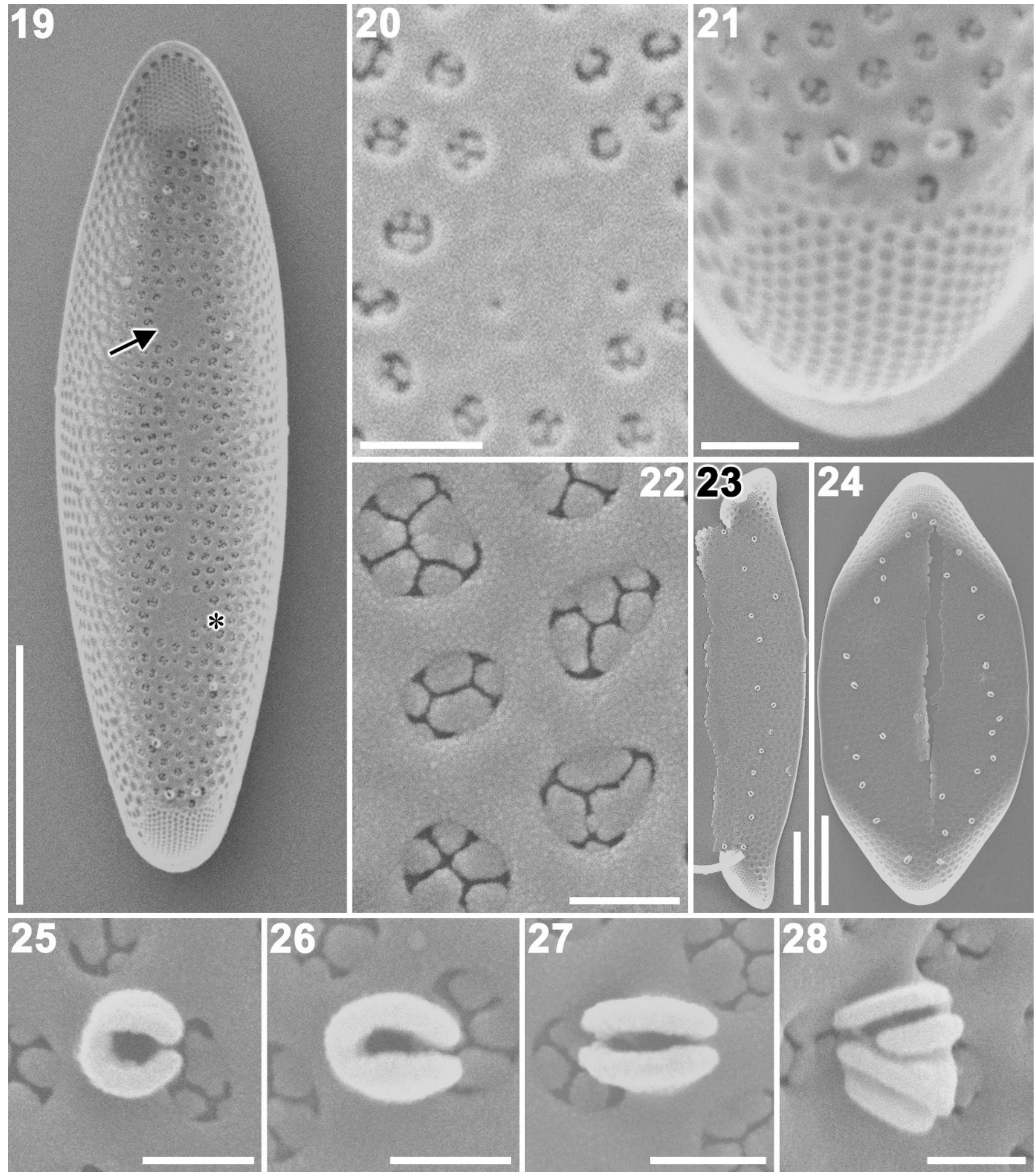

Figs 19-28. Pseudostriatella oceanica valves: internal views (SEM). Scale bars $=5 \mu \mathrm{m}$ (Fig. 19), $0.5 \mu \mathrm{m}$ (Figs 20, 21), $0.2 \mu \mathrm{m}$ (Figs 22,25 28) or $0.3 \mu \mathrm{m}$ (Figs 23, 24).

Fig. 19. Whole interior. The arrow indicates the hyaline area. Note the many irregularly scattered rimoportulae.

Fig. 20. Enlarged view of part marked by asterisk in Fig. 19 showing a few small, simple pores within the hyaline area.

Fig. 21. Detail of apical pore field.

Fig. 22. Areolae occluded by pegs, which are slightly recessed below the internal valve surface.

Figs 23, 24. Broken valve showing irregularly distributed rimoportulae around the valve margin.

Figs 25, 26. Circular and elliptical C-shaped rimoportulae.

Fig. 27. Normal 'labiate' rimoportula.

Fig. 28. Compound rimoportula. 

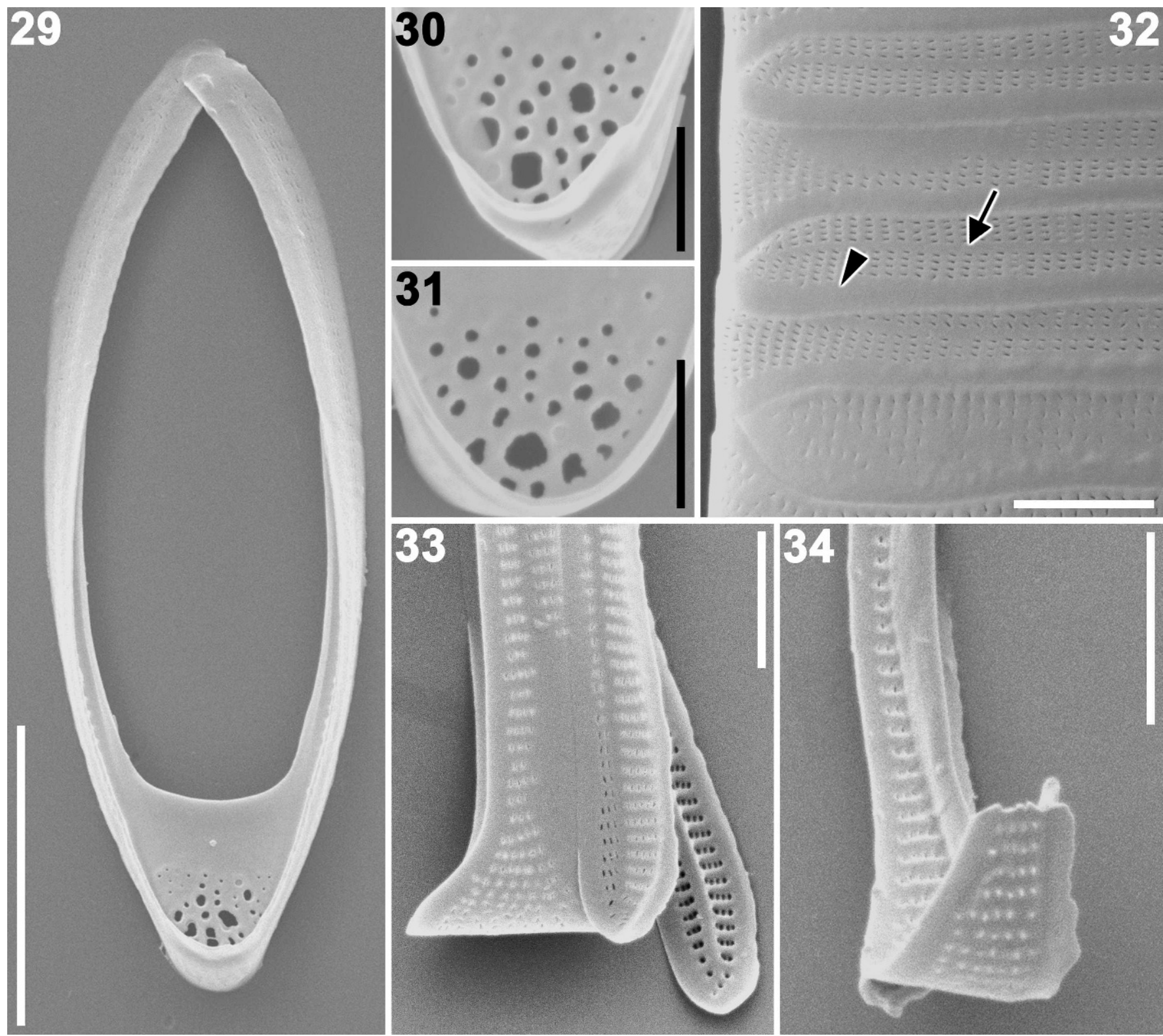

Figs 29-34. Pseudostriatella oceanica girdle (SEM). Scale bars $=5 \mu \mathrm{m}$ (Fig. 29), $1 \mu \mathrm{m}$ (Figs 30, 31) or $2 \mu \mathrm{m}$ (Figs 32-34).

Fig. 29. Single band with a perforated septum.

Figs 30, 31. Variation of perforation pattern in septa.

Fig. 32. Complete girdle showing interlocking bands. Note the regular striation, except for a hyaline area along the long axis (arrow) and advalvar edge (arrowhead).

Fig. 33. Disrupted cingulum showing the outside and inside of an open end. (right) and the outside of a closed end. The plain longitudinal strip is thickened and rib-like. Note that the interstriae region are also rib-like.

Fig. 34. Broken copula showing the inside of a closed end. Note that the longitudinal rib becomes more prominent and widens into the septum.

regarded as a longitudinal perizonial (LP) band ( $c f$. Fig. 54). No transverse perizonial (TP) bands were seen in this stage. The LP band comprised a longitudinal rib and a series of closely spaced ribs extending out from it at right angles (Fig. 43). At this stage, the body of cell appeared lumpy, which may represent chloroplasts within the auxospore or a partial covering of silica scales (see below).

When the expansion was complete, an initial valve was produced within the auxospore (Fig. 44). By then, the auxospore could be seen to possess not only longitudinal but also transverse bands (Figs 45, 46). The TP bands were very weakly silicified (Figs $45-47$ ) but could be seen to be finely and irregularly porous (Figs 46, 47, 49). Like the first LP band seen earlier in expansion, the TP bands also often consisted of a longitudinal rib bearing transverse ribs (Fig. 47, arrow and arrowhead, respectively), though these were very feebly developed. The ends of the transverse elements of the TP bands sometimes bore a fringe (Fig. 47).

The series of TP bands and LP bands covered the auxospore (Figs 48, 54). We will refer to the side closest to the theca of the auxospore mother cell as 'ventral', and it was on this side that the LP bands lay. There were several 

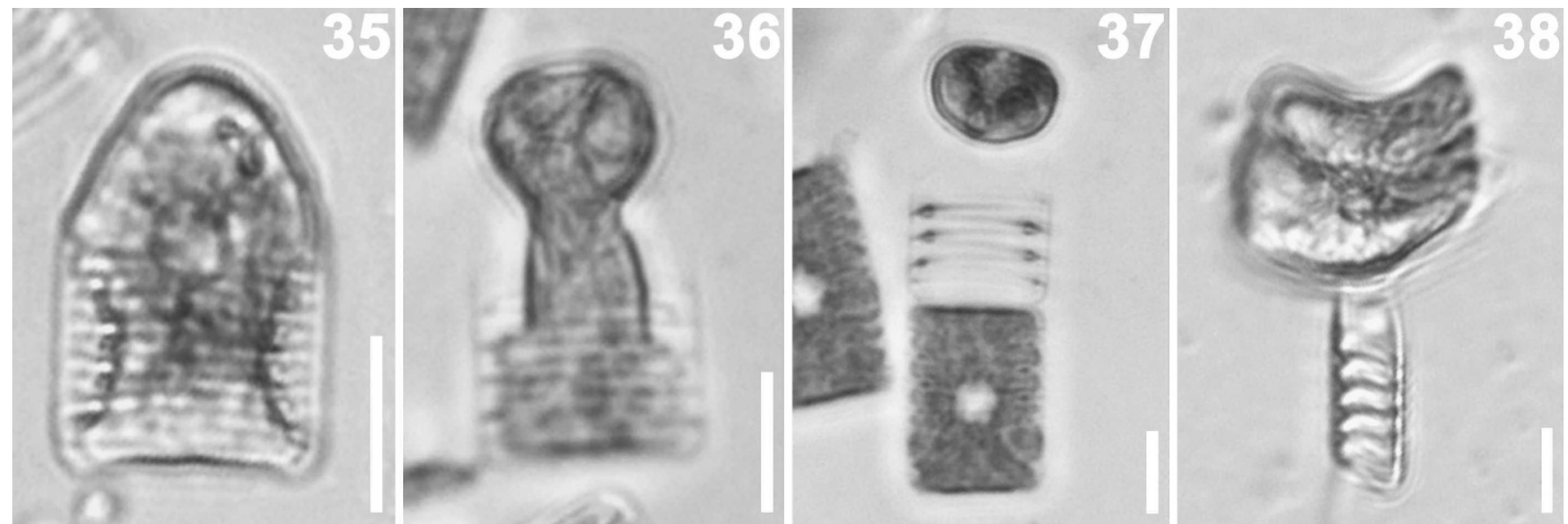

Figs 35-38. Pseudostriatella oceanica: clonal auxosporulation (LM). Scale bars $=10 \mu \mathrm{m}$

Figs 35, 36. Young auxospores being liberated from their mother cells.

Fig. 37. Contracted \pm spherical auxospore.

Fig. 38. Mature auxospore containing initial cell, lying slightly oblique to the object plane.
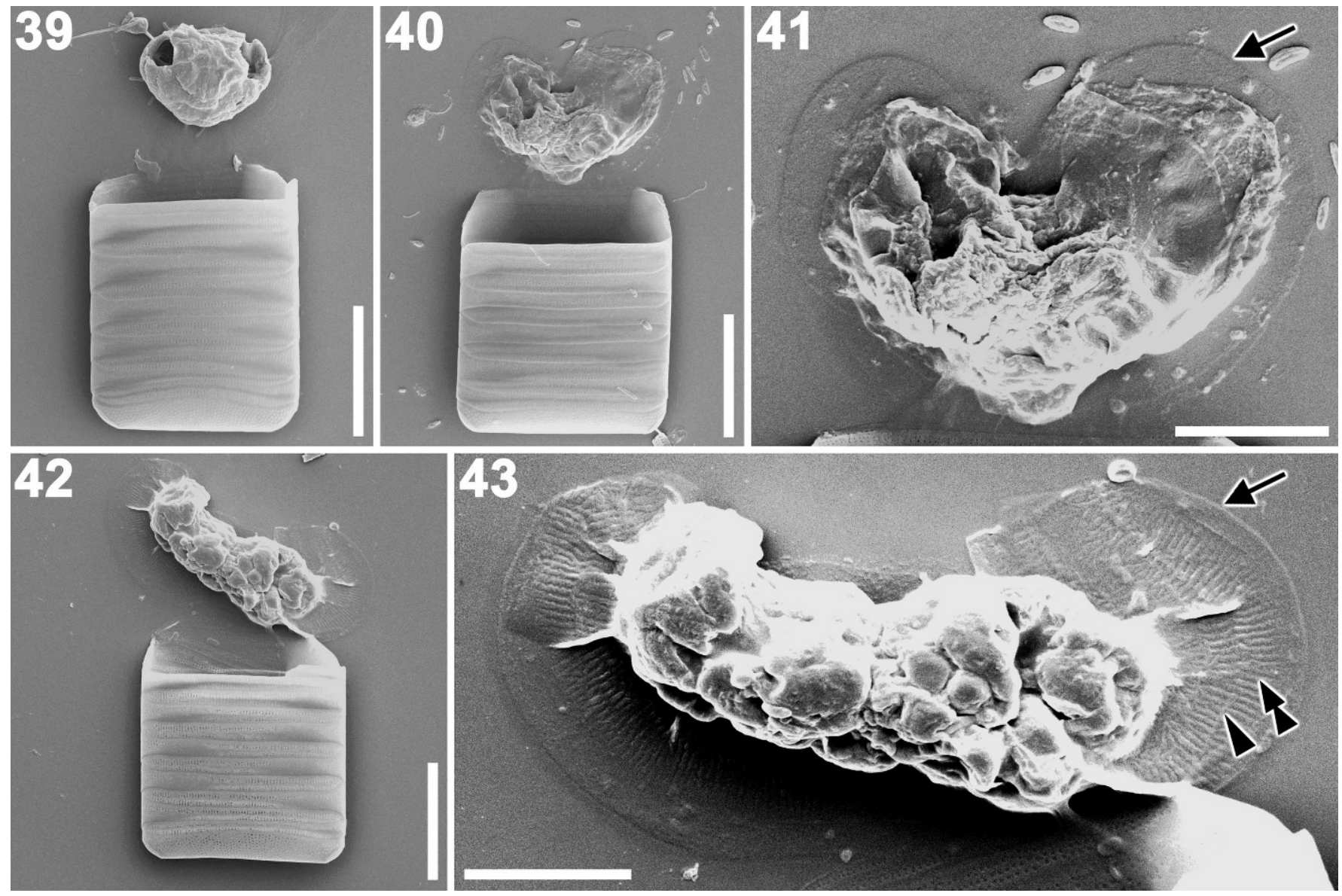

Figs 39-43. Pseudostriatella oceanica: early stages of auxosporulation (SEM). Scale bars $=10 \mu \mathrm{m}$ (Figs 39 , 40, 42) or $5 \mu \mathrm{m}$ (Figs 41 , 43). Fig. 39. Spherical auxospore. No covering is visible.

Fig. 40. Slightly expanded auxospore.

Fig. 41. Enlarged view of auxospore of Fig. 40. Arrow indicates mucilaginous layer covering auxospore.

Fig. 42. Expanding auxospore.

Fig. 43. Enlarged view of auxospore of Fig. 42. Arrow indicates mucilaginous layer. Arrowhead and double arrowhead indicate longitudinal and transverse ribs of a LP band, which has probably been bent during specimen preparation ( $c f$. Fig. 54). Note that a transverse perizonium is absent. 

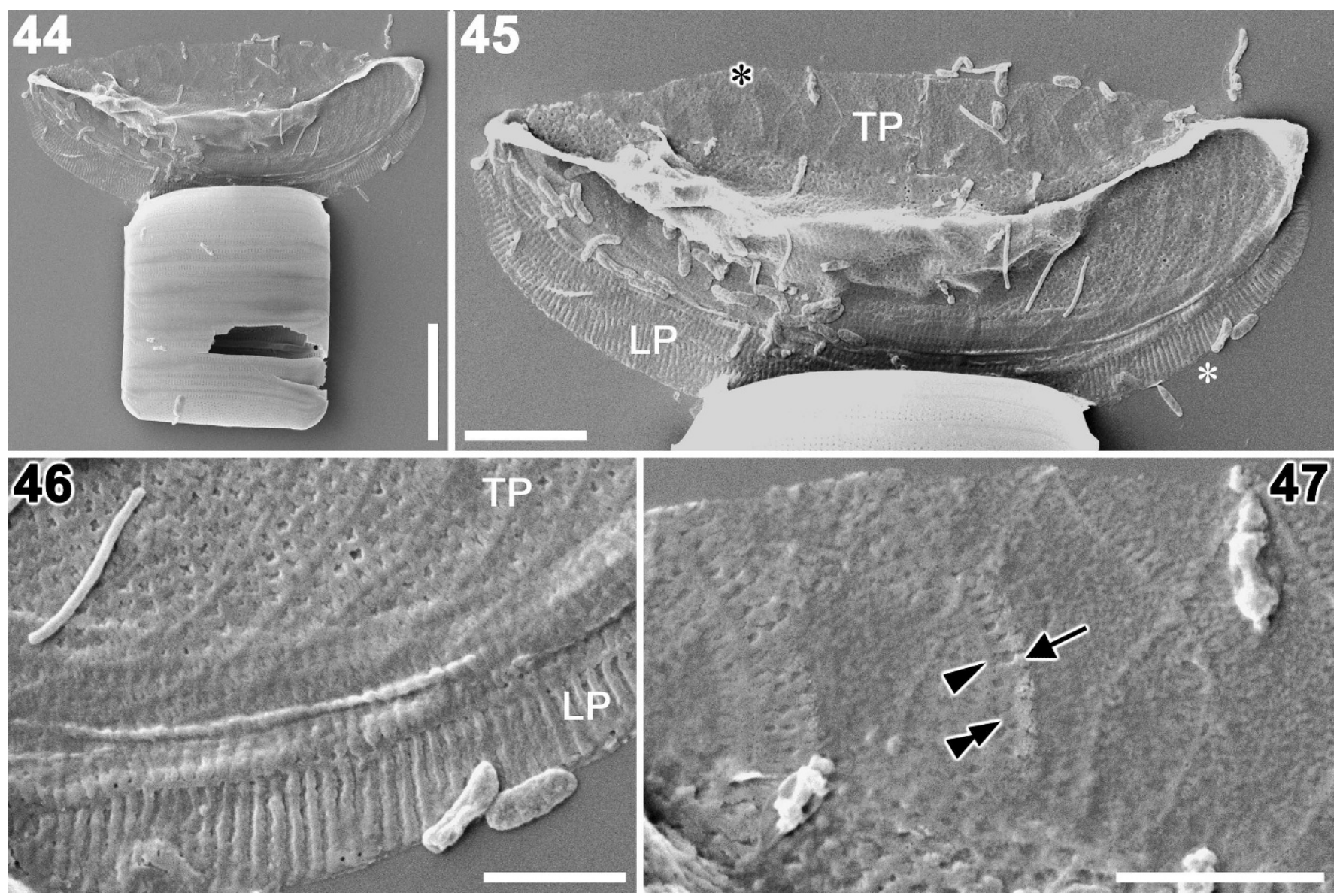

Figs 44-47. Pseudostriatella oceanica: fully expanded auxospore containing an immature initial epivalve (SEM). Scale bars $=10 \mu \mathrm{m}$ (Fig. 44), $5 \mu \mathrm{m}$ (Fig. 45) or $2 \mu \mathrm{m}$ (Figs 46, 47).

Fig. 44. Whole auxospore still associated with auxospore mother cell.

Fig. 45. Enlarged view of auxospore: the initial valve is detectable via its larger, coarser areolae, visible along the midline of the collapsed cell. The auxospore is covered by transverse perizonial bands (TP) dorsally and longitudinal perizonial bands (LP) ventrally.

Fig. 46. Enlargement (at black asterisk in Fig. 45), showing the structural differences between the transverse (TP) and longitudinal perizonial bands (LP).

Fig. 47. Enlargement (at white asterisk in Fig. 45), showing the delicate TP bands. No regular striae exist. The arrowhead and double arrowhead indicate the longitudinal and transverse ribs of a TP band, respectively; the arrow indicates a fringe.

TP bands (Fig. 49), all closed hoops except for the primary band, which was a simple strap passing from one side of the auxospore to the other (Fig. 54). The closed hoops, which we will refer to as secondary bands, did not girdle the auxospore fully. Instead, each was divided into two broader segments on the dorsal side of the auxospore, connected by a narrower strip along the ventral side (Figs 49, 54).

The primary band and the adjacent secondary TP band (Fig. 49: '1st' and '2nd', respectively) were so delicate and closely associated that the boundary between them was indistinct, and they may even have been fused together. The more distal TP bands ('3rd' and '4th' in Figs 49, 54) appeared to be slightly more robust than the first two bands and bore distinct longitudinal ribs. The fringed margins of the bands never interlocked with each other (except perhaps between the primary band and its neighbour) but overlapped from the centre outwards, the presumably older bands being external to the younger ones (Fig. 49). Rimoportulae were detected on the initial epivalve (Fig. 49). In fully expanded auxospores, scales were found on the ventral side (Fig. 50). They were thin and delicate and difficult to detect under SEM, unless a strongly contrasted image was produced. They varied in shape, but in the most frequent type there was a central pore field ringed by a prominent annulus bearing a delicate fringe of fine radiating fimbriae (Fig. 50, arrow). Much simpler scales were also found (Fig. 50, arrowhead), lacking the prominent annulus and fringe; they were sometimes fused to each other.

When initial cell formation was complete, the series of TP bands was released from the initial cell (Fig. 51, arrow). There were at least three LP bands. The widest lay furthest towards the ventral side (Fig. 52) and was always flanked in our images by two narrower bands (Figs 52, 53; see also Fig. 54). The transverse ribs of the LP bands were not straight, plain straps but sinuous or branched or even fused (Fig. 53).

\section{Phylogeny}

Highly variable regions were excluded from the $18 \mathrm{~S}$ rDNA alignment. The analysis used 1713 aligned positions, and 
for this, $P$. oceanica differed from its closest relative, $S$. unipunctata, in 104 substitutions and 28 indels.

A Bayesian tree inferred from 18S rDNA sequences of 174 diatoms and seven Bolidophyceae (Table 1) confirmed paraphyly for the araphid diatoms within a robust clade of pennate diatoms (Fig. 55). The same result was also obtained with NJ, MP and ML analyses (topologies not shown). Within the pennates, the Asterionellopsis RoundAsteroplanus Gardner \& Crawford-Talaroneis Kooistra \& De Stefano clade and Rhaphoneis cf. belgica emerged first, and then a clade containing all other sequenced araphid pennates and a clade of raphid diatoms diverged (Fig. 55; the outgroup centric diatoms and bolidomonads have been omitted for clarity). Pseudostriatella oceanica formed a robust monophyly with $S$. unipunctata, this in turn emerging from within raphid diatoms, being sister to the genus Achnanthes Bory (MP) or Eunotia Ehrenberg (NJ, ML and BI; only the Bayesian tree is shown in Fig. 55).

\section{DISCUSSION}

\section{Taxonomic comment on the order Striatellales and the} family Striatellaceae

Round et al. (1990) proposed that the genus Striatella Agardh should be regarded as a monospecific genus because the other (rarely reported) species assigned to it (Van Landingham 1978) differ from the type species $S$. unipunctata. We have encountered and isolated only $S$. unipunctata during this study, and the plastids and fine structure of the other species are unknown. Two of the 12 species considered to be valid by Van Landingham (1978) have been transferred to Hyalosira Kützing by Navarro \& Williams (1991). There are thus 10 species currently in the genus Striatella.

Striatella is the nominate genus of the order Striatellales, which was established by Round et al. (1990) and contains the single family Striatellaceae (Kützing 1844). In turn, Round considered the Striatellaceae as comprising three marine benthic genera: Striatella, Hyalosira and Grammatophora Ehrenberg. Judging by the description given by Round et al. (1990, p. 655) for the Striatellales, these three genera were linked because they have a narrow or indistinct sternum, well-differentiated apical pore fields (in which the pores are in a strict hexagonal array) and porous septate girdle bands. They also have a rimoportula at each apex. Molecular phylogenies show, however, that although Hyalosira and Grammatophora form a clade, this does not contain Striatella, nor is it a close relative of Striatella (Fig. 55; see also Sims et al. 2006, fig. 2). These results suggest that the family Striatellaceae and the order Striatellales should contain only the nominate genus Striatella and Pseudostriatella; the monophyly of this group is strongly supported by $18 \mathrm{~S}$ rDNA data, and a wider taxonomic revision is currently in preparation using multiple gene markers. With the benefit of hindsight, it is noticeable that Striatella differs from Hyalosira and Grammatophora in the arrangement of the sternum and rimoportula. The rimoportula is adjacent or lateral to the sternum in Hyalosira and Grammatophora (Round et al.
1990; our unpublished observations), but in Striatella they are not associated with each other. Instead, the sternum ends some distance short of the apical pore field, and the rimoportula lies within a small area of apically orientated striae. The rimoportulae lie within the striae in Pseudostriatella also but are not restricted to the cell apex.

\section{Comparison of Pseudostriatella and Striatella}

There are many morphological and ecological similarities between $P$. oceanica and $S$. unipunctata, such as the numerous copulae and their areolation and prominent septa, the attachment of cells to substrata in the marine littoral and sublittoral by a long mucilaginous stalk and the production of this stalk via a rimmed apical pore field (ocellus). Because of the morphological similarities of $P$. oceanica and $S$. unipunctata, especially with LM, it is quite possible that the species has been misidentified as $S$. unipunctata in the past. On the other hand, there are also many differences, which we regard as sufficient to differentiate these taxa at the rank of genus. The most striking features are the unusual striation, prominent hyaline area, pegged areolae, multiple marginal rimoportulae and perforated septum. Furthermore, if living specimens are obtainable, it is easy to identify them because the plastids of S. unipunctata are unmistakable because of their rod shape and radial arrangement (Fig. 56). With care, cleaned material of the genera can also be separated in LM. Thus, in $S$. unipunctata, each corner of the frustule is sharply truncated (Fig. 56) because of the sunken apical pore fields (see Round et al. 1990, p. 432, figs d, e); whereas, rounded corners occur in $P$. oceanica (Figs 2-4). Again, in valve views of $S$. unipunctata, the sternum is prominent and runs almost the whole length of the valve, the striae are regularly arranged (with staggered areolae giving a pattern of transversely orientated diamonds) and can be observed (Fig. 57) and the apical rimoportulae are clearly visible; none of these features exist in P. oceanica (Figs 5, 6).

Pseudostriatella oceanica is smaller than S. unipunctata. The range observed for $P$. oceanica $(16.0-47.8 \mu \mathrm{m})$ is probably close to the maximum for the species because we observed both auxospore mother cells and initial cells. It is possible that smaller cells may be formed on occasion because cells of other species sometimes continue to divide after the minimum threshold for sexual reproduction has been passed (Geitler 1932). Furthermore, the sizes of the initial cells can sometimes depend on the sizes of the gametangia or auxospore mother cells (Davidovich 2001), and this seems to be true in S. unipunctata (Chepurnov in Roshchin 1994, table 12). However, S. unipunctata can attain lengths of more than double the maximum seen in $P$. oceanica. Because $S$. unipunctata is widespread in tropical, subtropical and temperate climate zones (Witkowski et al. 2000), there are many records and measurements of this species (e.g. Van Landingham 1978). The widest range, 35$125 \mu \mathrm{m}$, is given by Hustedt (1931). Chepurnov in Roshchin (1994) observed sexual auxosporulation of S. unipunctata in culture and found that gametangia of $32-42 \mu \mathrm{m}$ gave rise to initial cells of $107-126 \mu \mathrm{m}$; in his illustrations the largest auxospore is $154 \mu \mathrm{m}$ long (measured on his plate 29). In monoclonal cultures (which cannot auxosporulate because 

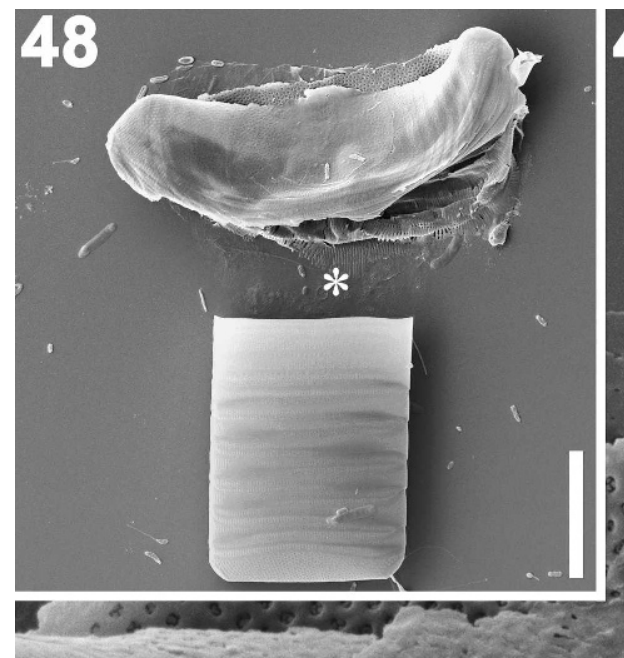
4 th $3 r d$ 2nd
49
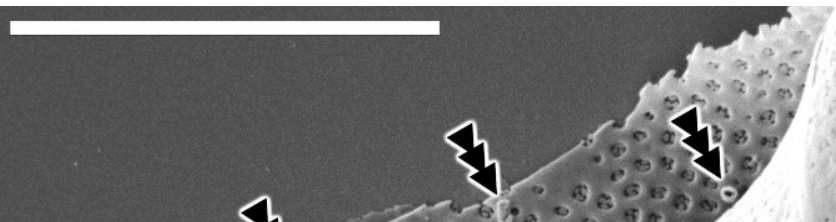

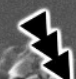

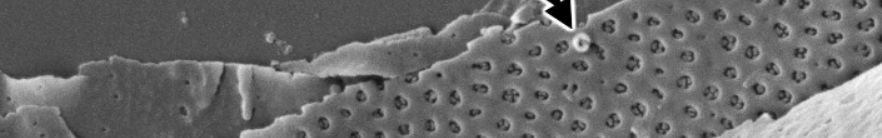

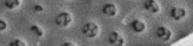

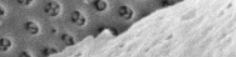

3.

1 st
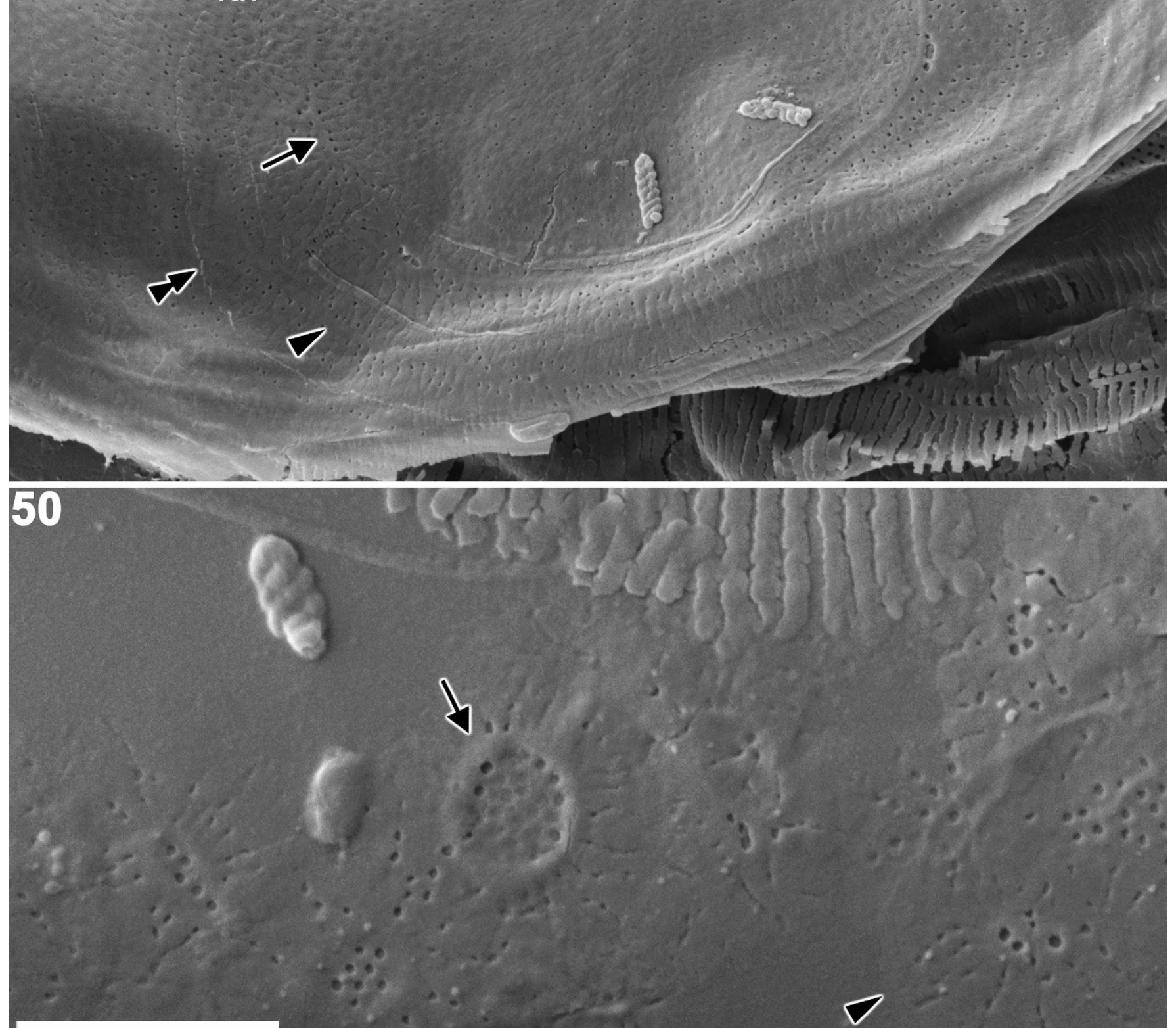

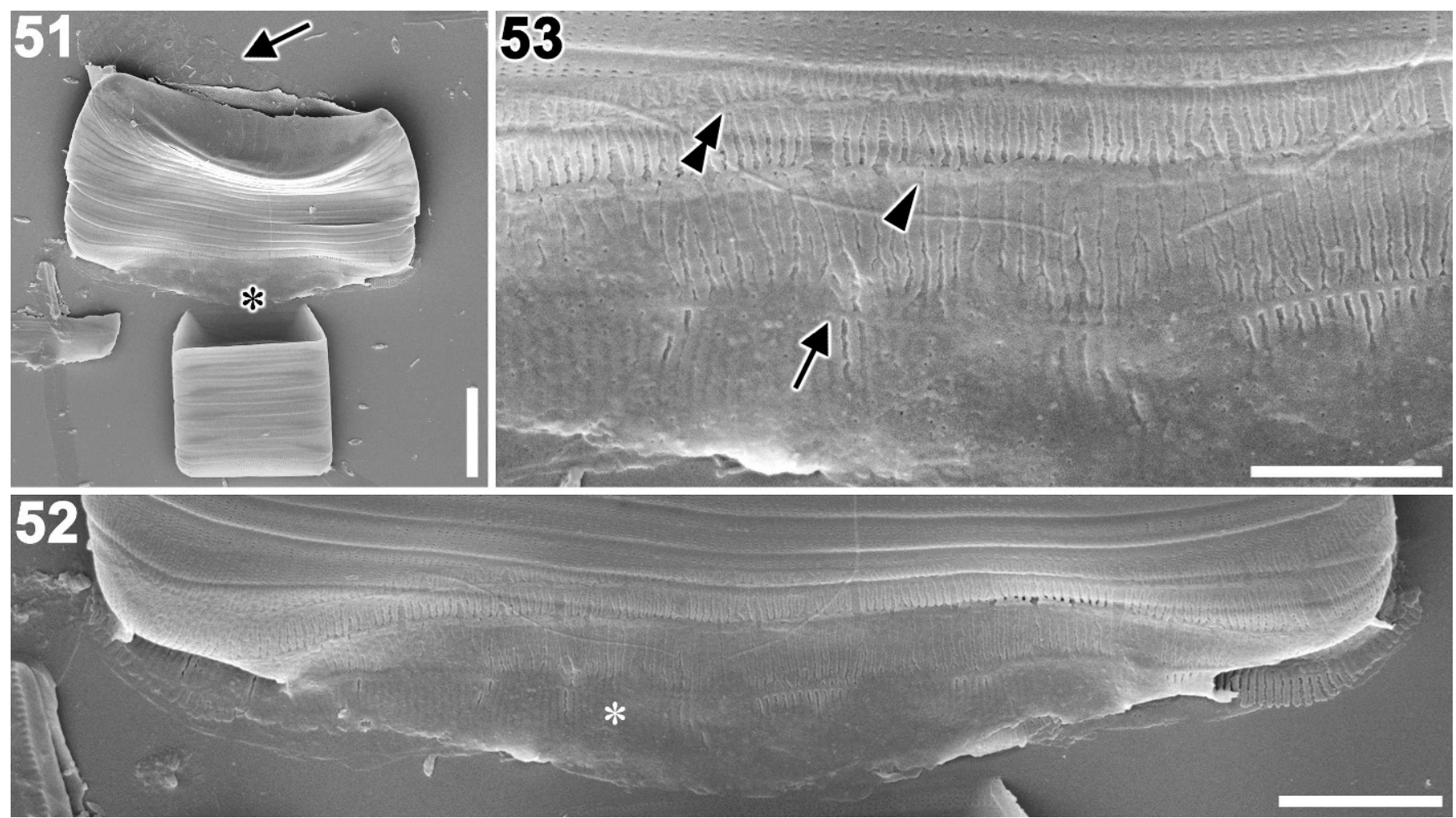

Figs 51-53. Pseudostriatella oceanica: initial cell still within auxospore envelope (SEM). Scale bars $=10 \mu \mathrm{m}$ (Fig. 51$)$, $5 \mu \mathrm{m}$ (Fig. 52$)$ or $3 \mu \mathrm{m}$ (Fig. 53).

Fig. 51. Whole initial cell, with auxospore mother cell still attached. The series of TP bands (arrow) appears to be detaching from the initial cell.

Fig. 52. Enlarged view of area marked by black asterisk in Fig. 51, showing the series of LP bands.

Fig. 53. Enlarged view of area marked by white asterisk in Fig. 52. The LP appears to consist of three bands - primary (arrow), secondary (arrowhead) and tertiary (double arrowhead) - but collapse of the auxospore may have hidden two other bands (cf. Fig. 54).

S. unipunctata is dioecious), some cells continued to divide until they were $22 \mu \mathrm{m}$ long before dying. Overall, therefore, although the size ranges of $P$. oceanica and $S$. unipunctata do overlap, they differ enough that valve length can help to distinguish the species in LM.

\section{Rimoportula function}

In araphid diatoms, there is some variation in the distribution of the rimoportulae; although, they are most often located along the long axis, mostly near one or both ends of the sternum. Normally, too, each rimoportula has its own special opening externally, which is separate and different from the external openings of the areolae. The consistency of these features suggests that they are maintained by selection, but their significance is unknown because the function of the rimoportula is unclear. In some cases, it has been shown that diatoms secrete mucilage through the rimoportula for movement, as in Actinocyclus Ehrenberg (Medlin et al. 1986) and Odontella Agardh (Pickett-Heaps et al. 1986), or adhesion, as in Melosira Agardh (Crawford 1975) and Aulacodiscus Ehrenberg (Sims \& Holmes 1983, p. 270). Schmid (1994) has suggested that the internal part of the rimoportula is used as a cytological anchor for the nucleus during interphase and new valve formation, and recently Kühn \& Brownlee (2005) have provided evidence that the rimoportula is a site for endocytosis and therefore involved in membrane recycling. It is quite possible that rimoportulae serve multiple roles in diatoms (Medlin et al. 1986). In P. oceanica, the rimopor-

$\leftarrow$

Figs 48-50. Pseudostriatella oceanica: final stage of auxosporulation (SEM). Scale bars $=10 \mu \mathrm{m}(\mathrm{Fig}$. 48) and $5 \mu \mathrm{m}$ (Fig. 49) and $2 \mu \mathrm{m}$ (Fig. 50).

Fig. 48. Auxospore containing a mature initial epivalve.

Fig. 49. Enlarged view of middle of auxospore of Fig. 48, showing that the initial valve is covered by TP and LP (bottom right) bands. TP bands are numbered from primary (1st) to fourth (4th). Note fuzzy border of 1 st and 2 nd bands. Bands 1 and 2 do not have rib thickenings, whereas bands 3 and 4 bands do (arrow and double arrowhead, respectively). The edge of band 4 overlap onto band 5 (double arrowhead). Triple arrowheads indicate rimoportulae at internal initial valve.

Fig. 50. Enlargement of area marked by asterisk in Fig. 48, showing scales on the ventral side of the auxospore. Two types are present, with (arrow) and without (arrowhead) an annulus. 


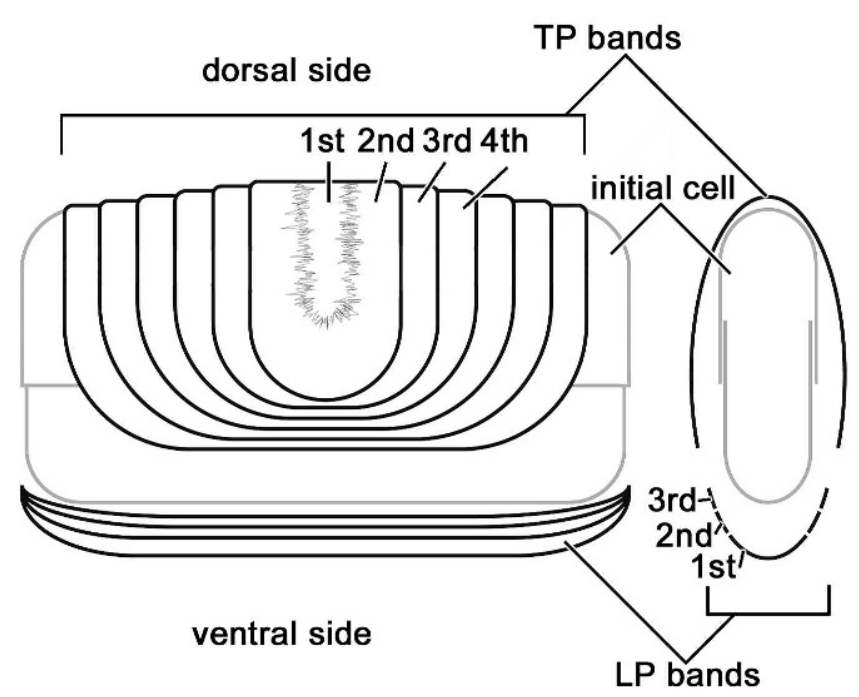

Fig. 54. Pseudostriatella oceanica: plan diagram and section (right) of 'perizonium' and initial cell.

tulae have no external openings of their own and connect to the outside instead through part of an areola (Figs 25-28). This, together with their scattered distribution on the valve, makes it unlikely that the rimoportulae function in movement in $P$. oceanica or in the production of robust structured mucilage for adhesion. Altogether, the characteristics of the rimoportulae in $P$. oceanica suggest relaxed functional constraints, relative to other araphid pennates.

On the other hand, the rimoportulae have not been lost altogether in $P$. oceanica, in contrast to members of the Plagiogrammaceae (including Talaroneis, Dimeregramma Ralfs and Plagiogramma Paddock) and other genera, such as Staurosira (Ehrenberg) Williams \& Round, Nanofrustulum Round, Hallsteinsen \& Paasche, Opephora Petit, Punctastriata Williams \& Round, Staurosirella Mereschkowsky, Pseudostaurosiropsis Morales and Pseudostaurosira Williams \& Round (Round et al. 1990, 1999; Morales 2001, 2005; Kooistra et al. 2004). Among these rimoportula-lacking diatoms, few seem to be able to grow as epiphytes - possibly only Talaroneis (Kooistra et al. 2004); the rest grow attached to rocks or sand grains or live planktonically. Possession of rimoportulae may therefore be important in araphid pennates for attachment to plants.

\section{Phylogeny}

The 18S rDNA phylogeny gave strong support not only to the monophyly of the $P$. oceanica-S. unipunctata clade (Bootstrap supports in NJ and ML analyses = 100; Bayesian posterior probability $=1.0$ ) but also to the establishment of a new genus for $P$. oceanica because of the long branches connecting both species. The high divergence between these taxa (104 substitutions and 28 indels) contrasts, for example, with the shorter branch lengths within Grammatophora Ehrenberg and Eunotia (see Fig. 55). We accept, of course, that there is no absolute standard for the amount of sequence difference that justifies generic status. Although P. oceanica and S. unipunctata lie at the ends of long branches, the possibility that the tree has been distorted by long-branch artifacts can probably be excluded because the two taxa also share a very long node with high statistical support. Preliminary analyses using several gene markers also show that monophyly of the clade containing the two genera is robust (S. Sato, unpublished observations).

Many phylogenetic studies of diatoms made using 18S rDNA have revealed that the araphid pennate diatoms are paraphyletic. They divide into two groups: (1) a relatively small clade of marine diatoms containing the Rhaphoneidaceae, Plagiogrammaceae, Asterionellopsis and Asteroplanus and (2) a larger, 'core' group (grade) containing the rest of the araphid diatoms that is the sister group to the raphid diatoms (e.g. Medlin \& Kaczmarska 2004; Alverson et al. 2006; Sims et al. 2006). This relationship was recovered in the present analysis. Some features of our tree, such as the sister relationship between the $P$. oceanica-S. unipunctata clade and the raphid genus Eunotia, have high support but are frankly implausible because of morphological and reproductive evidence. For example, the pattern of auxosporulation in Striatella (cis anisogamy coupled with expansion of the auxospore at the mouth of the female gametangium and at right angles to it: Chepurnov in Roshchin 1994) is not shared by Eunotia (Mann et al. 2003) or with any other raphid diatoms (Round et al. 1990) but does agree well, though not perfectly, with auxosporulation in Rhabdonema Kützing and Grammatophora (von Stosch 1962; Sato et al. 2008a). There are also no vestiges of a raphe in Pseudostriatella (contrast Cocconeis Ehrenberg 'pseudoraphe' valves, Semiorbis R. Patrick and some Asterionella-like diatoms; Mann 1982a; Round et al. 1990; Kociolek \& Rhode 1998). The poorly supported relationship to the raphid diatoms probably results from wellknown analytical artifacts, such as taxon sampling or substitution bias: the long branches seen in $P$. oceanica-S. unipunctata clade suggest an accelerated rate of base substitution, which may make it difficult to reconstruct the phylogeny correctly.

Indeed, 18S rDNA analyses undertaken so far have placed S. unipunctata in various phylogenetic positions. Some put the genus at the root of the raphid diatoms (Kooistra et al. 2003a, b, 2004). Given the hypothesis of Hasle (1974) that the rimoportula might be the predecessor of the raphe, Kooistra et al. (2003a) implied that the slightly elongated external opening of the rimoportula in Striatella illustrates how the raphe could have arisen, by elongation towards the centre of the valve, creating two slits splitting the sternum. By contrast, in Medlin \& Kaczmarska's (2004) analyses, the sister to Striatella is Staurosira construens Ehrenberg, which has no morphological features in common with Striatella and Pseudostriatella beyond its elongate shape (Round et al. 1990). In an 18S rDNA tree using almost the same data set of Medlin \& Kaczmarska (2004) but constructed by direct optimization (DO), a heuristic maximum parsimony algorithm, Striatella is sister to the marine araphid genus Licmophora Agardh (Sorhannus 2004). Finally, the genus has appeared within the raphid diatoms, as sister to an Anomoeoneis PfitzerCymbella Agardh clade (Medlin et al. 2000). None of these relationships are robust (i.e. they receive low bootstrap support or Bayesian posterior probabilities; statistical support data are not available in Sorhannus 2004). 


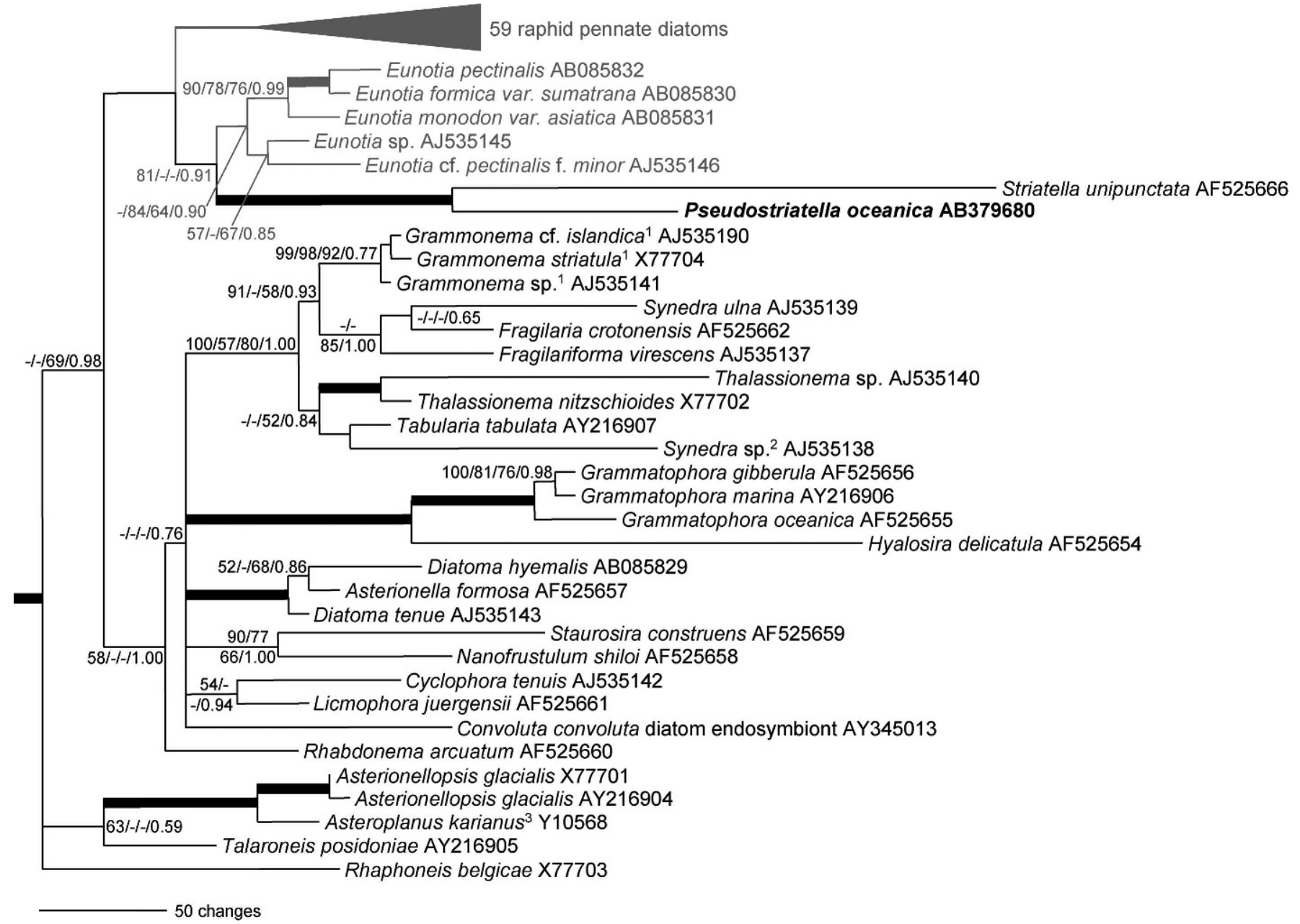

Fig. 55. Molecular phylogeny of araphid pennate diatoms inferred from $18 \mathrm{~S}$ rDNA sequence using 1713 aligned positions. The tree shown resulted from Bayesian inference using a GTR + I + G model. Outgroup bolidomonads and centric diatoms were excluded, and a clade comprising raphid diatoms is collapsed into triangle for clarity. Nodal support values greater than 50 (NJ, MP and ML) and 0.50 (BI) are shown. Nodes with strong supports (bootstrap support > 90 in NJ, MP and ML, and posterior probability $>0.95$ in BI) are shown as thick lines. ${ }^{1}$ Name change since deposit; ${ }^{2}$ likely a new genus collected from a marine habitat (Medlin et al. 2008a); ${ }^{3}$ annotated as Asterionellopsis kariana in GenBank.

One recent result from a Bayesian 18S rDNA analysis, using a doublet model that takes base substitutions in rRNA secondary structure into account, constructed a robust Striatella-Rhabdonema clade as one of a radiated group of pennate diatoms (Alverson et al. 2006, fig. 5). However, the consensus most parsimonious tree disconnected Striatella from Rhabdonema and put the taxa into polytomy (Alverson et al. 2006, fig. 6). Sims et al. (2006) used a huge data set that placed Striatella at the root of the 'core' araphid + raphid clade with high support. In the ML tree presented by Sorhannus (2007), Striatella also diverges at the root of the core araphid clade but with low bootstrap support.

We conclude, therefore, that it is probably impossible at this time to obtain a fully resolved phylogeny resolving the correct phylogenetic placement of the $P$. oceanica-S. unipunctata clade, and it may remain impossible when $18 \mathrm{~S}$ rDNA sequences are used in a single gene phylogeny. It is particularly important to establish the position of the clade because of the unusual structure of the auxospore (see below) and pattern centre in $P$. oceanica. The pennate diatoms are usually monophyletic in trees based on a variety of genes (molecular studies of diatoms are listed by Mann \& Evans 2007), supporting the idea that the 'pennate' Bauplan is a synapomorphy, that is, the possession of a single longitudinal rib-like element (sternum) at the centre of the pattern and deposited first during valve formation, which subtends sets of transverse ribs on either side (e.g. Round et al. 1990, p. 31). Some diatoms previously regarded as 'pennates', such as Toxarium, Ardissonea and Climacosphenia, which have a different kind of pattern centre (Mann 1984), have been shown to belong outside the pennate clade (Kooistra et al. 2003b; Alverson et al. 2006; Medlin et al. 2008b). However, the pattern centre in $P$. oceanica is unlike anything found previously in pennate diatoms partly because it is a wide unthickened hyaline area but more importantly because its wider terminal sections contain pores. In fact, the hyaline area resembles a highly elongate annulus - a more extreme version of the elongate annuli seen in some Odontella (e.g. Pickett-Heaps et al. 


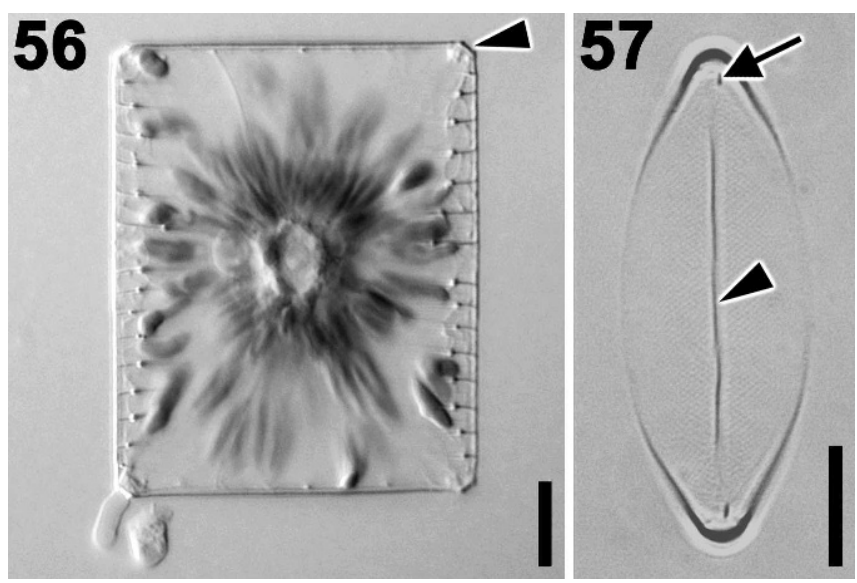

Figs 56, 57. Striatella unipunctata (LM). Scale bars $=10 \mu \mathrm{m}$.

Fig. 56. Living cell showing distinctive plastids. Arrowhead indicates truncated corner of cell.

Fig. 57. Cleaned valve taken with phase contrast optics. Arrow indicates rimoportula, arrowhead indicates sternum.

1990, fig. 40e) and Attheya species (Crawford et al. 1994). Until a robust phylogeny is available, it will be unclear whether the resemblance between the Pseudostriatella pattern centre and an annulus is a symplesiomorphy (i.e. Pseudostriatella does not have and has never had a true sternum) or the result of convergent evolution.

\section{Auxosporulation and auxospore fine structure}

We were not able to establish how the auxospores arise in monoclonal cultures of $P$. oceanica because the earliest stages were not seen. It is very unlikely that the auxospores developed through allogamous sexual reproduction because we are confident that we would have observed the empty frustules of any 'male' cells close to the expanding auxospores (Roshchin 1994; Chepurnov et al. 2004). Therefore, we have referred to the auxosporulating cells as 'auxospore mother cells' rather than as gametangia. Further work is needed to determine whether auxosporulation involves meiosis and automictic fusion or whether it is apomictic. Nonallogamous formation of auxospores and vegetative cell enlargement has been recorded in other araphid pennates, including Grammatophora (Sato et al. 2008a) and Licmophora (Kumar 1978).

The structure of the auxospore in $P$. oceanica is unlike anything described so far and prompts re-examination of the nature of 'perizonia' and 'properizonia'. In its overall layout, the auxospore casing of $P$. oceanica resembles the envelopes of Rhabdonema (von Stosch 1962, 1982), Gephyria (Sato et al. 2004) and Grammatophora (Sato et al. 2008a) in that it possesses small more or less isodiametric or slightly elongate scales and also a separate series of longitudinal and transverse bands. However, there are also significant differences, notably in the structure of the transverse bands and the spatiotemporal organization of auxospore development.

There are very few scales in $P$. oceanica, compared to other araphid diatoms (Sato et al. 2004, 2008a, b), and we found them only on the mature auxospore (although we cannot wholly exclude that they were present). As in other diatoms (e.g. von Stosch 1962, 1982; Crawford 1974; Kobayashi et al. 2001; Schmid \& Crawford 2001), the scales varied in shape within a single auxospore. Some scales had an annulus and were morphologically similar to those of centric diatoms (Round et al. 1990). In P. oceanica, the auxospores never had a complete covering of scales. The few scales present were restricted to the ventral side in nearly mature or mature examples. A ventral distribution is also present in fully developed auxospores of the mediophycean centric diatom Chaetoceros didymum Ehrenberg (von Stosch 1982, fig. 2), although here the scales can also be detected from the earliest stages (von Stosch et al. 1973; von Stosch 1982).

Some details of perizonial structure were obscured by collapse of the auxospore during air drying. However, the widest LP band was always located at the most ventral end (Fig. 52), and it was associated with two additional bands. We therefore infer that the widest band is the primary band and that the additional bands flanking it are a secondary and a tertiary LP band (Fig. 54). We believe, however, that some of the LP bands were hidden by folding of the auxospore, which seems likely because all of the longitudinal perizonia reported so far in pennate diatoms are structurally symmetrical (e.g. von Stosch 1962, 1982; Mann 1982b; Toyoda et al. 2005), even in Amphora (Nagumo 2003). There would therefore be five longitudinal bands in $P$. oceanica (Fig. 54), and a similar arrangement has been found in Tabularia parva (Sato et al. 2008b). Interestingly, even though the valves of $P$. oceanica have a poorly expressed and irregular sternum-stria system, the LP bands have strictly parallel patterning, resembling the striation of normal araphid diatom valves.

The usual structure of the transverse perizonium in pennate diatoms - both araphid and raphid - is that there is a central primary band with a separate series of secondary bands on each side (von Stosch 1982; Mann 1982b). The primary band is either a short cylinder wholly encircling the centre of the auxospore (i.e. it is 'closed': e.g. Poulíčková \& Mann 2006), or it is a split ring (an 'open' band) with its ends almost touching (e.g. Sato et al. 2004). The secondary bands are usually open, again with their ends closely associated. The TP bands combine to form a cigar-shaped perizonium with a narrow ventral suture, beneath which there is often a set of LP bands, again differentiated into a central primary band and two short flanking series of secondary bands (e.g. Mann 1982b; Mann \& Stickle 1993; Nagumo 2003; Sato et al. 2004; Toyoda et al. 2005). The function of the perizonium appears to be to support and constrain anisometric expansion of the auxospore (Mann 1994).

Many centric diatoms also exhibit anisometric expansion, and again this is apparently controlled through the formation of band-shaped stiffening elements, which together constitute a structure called the 'properizonium' (von Stosch 1982). The key difference between properizonia and perizonia identified by von Stosch (von Stosch \& Kowallik 1969; von Stosch et al. 1973; von Stosch 1982) is that perizonia are independent from the original zygote wall both structurally and developmentally (the perizonium is 'eine von der ursprünglichen Zygotenhülle unabhängige Struktur': von Stosch \& Kowallik 1969, p. 469). In 
contrast, properizonia are supposed to be structurally and developmentally continuous with the scale-containing layers that precede them (the otherwise helpful review by Kaczmarska et al. 2001 may be misleading in this respect). Thus, von Stosch (1982, p. 146) considered that, for the evolutionary transition from properizonial casings to perizonial diatoms like Rhabdonema, 'the first item necessary would be a developmental and spatial hiatus between scale layers and properizonial band systems'. No other features have been identified that are diagnostic for the perizonium vs the properizonium, but it is generally considered (von Stosch 1982; Round et al. 1990; Kaczmarska et al. 2001; Medlin \& Kaczmarska 2004) that perizonia are characteristic of pennate diatoms; whereas, properizonia are restricted to some lineages of multipolar centric diatoms. Our observations of $P$. oceanica revealed no clear developmental separation between a primary scalebearing wall and the 'perizonium'. Scales were rare and produced apparently only towards the end of auxospore expansion, and it appears too that longitudinal perizonial elements are produced before the transverse perizonium. In retrospect, we believe that a similar continuity of development may occur also in Gephyria, where we (Sato et al. 2004) detected scales on the inside of the primary TP band.

Another curious, 'transitional' feature of $P$. oceanica auxospores concerns the nature of the secondary TP bands. As noted above, the secondary bands on either side of the primary TP band are separate entities in the perizonia of all raphid and araphid pennates studied until now, as they are also in a few properizonia (those of Odontella and Biddulphia; von Stosch 1982). Pseudostriatella is quite different because the secondary TP elements are continuous from one end of the auxospore to the other around the ventral side (Fig. 54). Each is therefore a complex hoop, shaped like the margin of a saddle. Thus, although the expansion of the auxospore is bipolar in $P$. oceanica, the development of the TP itself is unipolar, beginning from the strap-like primary band and extending out both laterally (towards the poles) and ventrally. Exactly the same unipolar pattern of development occurs in the properizonia of Chaetoceros, Bacteriastrum, Attheya, Lithodesmium (here the topology is more complex, because most auxospores are triradiate) and Bellerochea (von Stosch 1982) and also in Lampriscus (Idei \& Nagumo 2002). Thus, it would be as reasonable to regard the auxospore casing of $P$. oceanica as a properizonium as it is to describe it as a true perizonium, despite the fact that this species clearly belongs phylogenetically to the pennate lineage. The presence of longitudinal elements in the Pseudostriatella casing is not conclusive support for interpretation as a perizonium because (1) longitudinal elements are present beneath the 'transverse' bands in the triradiate centric Lithodesmium (von Stosch 1982; see also Round et al. 1990) and (2) the longitudinal bands of $P$. oceanica seem to be formed before the transverse bands, whereas during perizonium formation in raphid diatoms the converse is true.

A simple conclusion can be drawn: there is simply too little information from too few taxa to allow detailed analysis of the evolution of auxospore structure, and the distinction between properizonia and perizonia needs to be re-evaluated. All that can be said at the moment is that classification into scaly, properizonial and perizonial auxospores ( $c f$. the 'isometric', 'anisometric' and 'bilateral' auxospores of Kaczmarska et al. 2001) is perhaps too simple but that the development of shape is generally associated with stiffening of the auxospore wall during expansion by silica bands and hoops.

\section{ACKNOWLEDGEMENTS}

The authors are grateful to Beth K. Petkus for collection of living specimen and brought us it from the United States to Germany with her, Richard M. Crawford for correction of the manuscript and discussion, Stephan Frickenhaus for establishing parallel processing for Bayesian analyses, Paul A. Fryxell for helping to translate the Latin diagnosis, Friedel Hinz for technical help for LM and SEM, and Masahiko Idei for allowing us to access his poster for the 17th International Diatom Symposium. We also thank two anonymous reviewers for their valuable comments and suggestions. This study was supported by DAAD for doctoral research fellowship to Shinya Sato.

\section{REFERENCES}

Altekar G., Dwarkadas S., Huelsenbeck J.P. \& Ronquist F. 2004. Parallel Metropolis-coupled Markov chain Monte Carlo for Bayesian phylogenetic inference. Bioinformatics 20: 407-415.

Alverson A.J., Cannone J.J., Gutell R.R. \& Theriot E.C. 2006. The evolution of elongate shape in diatoms. Journal of Phycology 42: 655-668.

Amato A., Orsini L., D’Alelio D. \& Montresor M. 2005. Life cycle, size reduction patterns, and ultrastructure of the pennate planktonic diatom Pseudo-nitzschia delicatissima (Bacillariophyta). Journal of Phycology 41: 542-556.

AnONYMous. 1975. Proposals for a standardization of diatom terminology and diagnoses. Nova Hedwigia, Beiheft 53: 323-354.

CAHOON L.B. 1999. The role of benthic microalgae in neritic ecosystems. Oceanography and Marine Biology. An Annual Review 37: 47-86.

Chepurnov V.A., Mann D.G., Sabbe K. \& Vyverman W. 2004. Experimental studies on sexual reproduction in diatoms. International Review of Cytology 237: 91-154.

Cohn S.A., Spurck T.P., Pickett-Heaps J.D. \& Edgar L.A. 1989. Perizonium and initial valve formation in the diatom Navicula cuspidata (Bacillariophyceae). Journal of Phycology 25: 15-26.

CRAWFORD R.M. 1974. The auxospore wall of the marine diatom Melosira nummuloides (Dillw.) C. Ag. and related species. British Phycological Journal 9: 9-20.

CRAWFORD R.M. 1975. The frustule of the initial cells of some species of the diatom genus Melosira C. Agardh. Nova Hedwigia, Beiheft 53: 37-50.

Crawford R.M., Gardner C. \& Medlin L.K. 1994. The genus Attheya. I. A description of four new taxa, and the transfer of Gonioceros septentrionalis and G. armatus. Diatom Research 9: 27-51.

Davidovich N.A. 2001. Species-specific sizes and size range of sexual reproduction in diatoms. In: Proceedings of the 16th International Diatom Symposium (Ed. by A. Economou-Amilli), University of Athens, Greece. pp. 191-196.

Elwood H.J., Olsen G.J. \& Sogin M.L. 1985. The small subunit ribosomal DNA gene sequences from the hypotrichous ciliates Oxytricha nova and Stylonichia pustulata. Molecular Biology and Evolution 2: 399-410. 
Eppley R.W., Holmes R.W. \& Strickland J.D.H. 1967. Sinking rates of the marine phytoplankton measured with a fluorochrometer. Journal of Experimental Marine Biology and Ecology 1: 191-208.

Geitler L. 1932. Der Formwechsel der pennaten Diatomeen. Archiv für Protistenkunde 78: 1-226.

Gillespie J.J., McKenna C.H., Yoder M.J., Gutell R.R., JohnStON J.S., Kathirithamby J. \& COgnato A.I. 2005. Assessing the odd secondary structural properties of nuclear small subunit ribosomal RNA sequences (SSU) of the twistedwing parasites (Insecta: Strepsiptera). Insect Molecular Biology 14: 625-643.

Guillou L., Chrétiennot-Dinet M.-J., Medlin L.K., Claustre H., LoiseAuX-DE GoËr S. \& VAulot D. 1999. Bolidomonas: a new genus with two species belonging to a new algal class, the Bolidophyceae class. nov. (Heterokonta). Journal of Phycology 35: $368-381$.

HALL T.A. 1999. BioEdit: a user-friendly biological sequence alignment editor and analysis program for Windows 95/98/NT. Nucleic Acids Symposium Series 41: 95-98.

HANCOCK J.M. \& Vogler A.P. 2000. How slippage-derived sequences are incorporated into rRNA variable-region secondary structure: implications for phylogeny reconstruction. Molecular Phylogenetics and Evolution 14: 366-374.

HASLE G.R. 1974. The 'mucilage pore' of pennate diatoms. Nova Hedwigia, Beiheft 45: 167-194.

HuelsenbeCK J.P. \& RonQuist F. 2001. MRBAYES: Bayesian inference of phylogeny. Bioinformatics 17: 754-755.

Hustedt F. 1931. Die Kieselalgen Deutschlands, Österreichs und der Schweiz. In: $\operatorname{Dr} L$ Rabenhorsts Kryptogamenflora von Deutschland, Österreich und der Schweizvol, vol. 7(2:1). Akademische Verlagsgesellschaft, Leipzig, Germany. pp. 1-176.

IdeI M. \& Nagumo T. 2002. Auxospore structure of the marine diatom genus Lampriscus with triangular/quadrangular forms. In: Abstracts, 17th International Diatom Symposium (Ed. by M. Poulin), Ottawa, Canada. 166 pp.

Kaczmarska I., Bates S.S., Ehrman J.M. \& Léger C. 2000. Fine structure of the gamete, auxospore and initial cell in the pennate diatom Pseudo-nitzschia multiseries (Bacillariophyta). Nova Hedwigia 71: 337-357.

Kaczmarska I., Ehrman J.M. \& Bates S.S. 2001. A review of auxospore structure, ontogeny and diatom phylogeny. In: Proceedings of the 16th International Diatom Symposium (Ed. by A. Economou-Amilli), University of Athens, Greece. pp. 153-168.

Kobayashi A., Osada K., Nagumo T. \& Tanaka J. 2001. An auxospore of Arachnoidiscus ornatus Ehrenberg. In: Proceedings of the 16th International Diatom Symposium (Ed. by A. Economou-Amilli), University of Athens, Greece. pp. 197-204.

KocioleK J.P. \& Rhode K. 1998. Raphe vestiges in Asterionella species from Madagascar: evidence for a polyphyletic origin of the araphid diatoms? Cryptogamie: Algologie 19: 57-74.

Kooistra W.H.C.F., De Stefano M., Mann D.G. \& Medlin L.K. 2003a. The phylogeny of the diatoms. Progress in Molecular and Subcellular Biology 33: 59-97.

Kooistra W., De Stefano M., Mann D.G., Salma N. \& Medlin L.K. 2003b. Phylogenetic position of Toxarium, a pennate-like lineage within centric diatoms (Bacillariophyceae). Journal of Phycology 39: 185-197.

Kooistra W.H.C.F., Forlani G., Sterrenburg F.A.S. \& De Stefano M. 2004. Molecular phylogeny and morphology of the marine diatom Talaroneis posidoniae gen. et sp. nov. (Bacillariophyta) advocate the return of the Plagiogrammaceae to the pennate diatoms. Phycologia 43: 58-67.

KÜHN S.F. \& BROwnleE C. 2005. Membrane organisation and dynamics in the marine diatom Coscinodiscus wailesii (Bacillariophyceae). Botanica Marina 48: 297-305.

KumAR R. 1978. Auxospore formation in species of the marine diatom Licmophora Agardh. Veröffentlichungen des Instituts für Meeresforschungen in Bremerhaven 17: 15-20.

KüTZING F.T. 1844. Die kieselschaligen Bacillarien oder Diatomeen. Nordhausen, Germany. $152 \mathrm{pp}$

MANN D.G. 1982a. Structure, life history and systematics of Rhoicosphenia (Bacillariophyta) I. The vegetative cell of $R h$. curvata. Journal of Phycology 18: 162-176.
MAnN D.G. 1982b. Structure, life history and systematics of Rhoicosphenia (Bacillariophyta). II. Auxospore formation and perizonium structure of Rh. curvata. Journal of Phycology 18: 264-274.

MANN D.G. 1984. An ontogenetic approach to diatom systematics. In: Proceedings of the 7th International Diatom Symposium $(\mathrm{Ed}$ by D.G. Mann), O. Koeltz, Koenigstein, Germany. pp. 113-144.

MANN G.D. 1994. The origins of shape and form in diatoms: the interplay between morphogenetic studies and systematics. In: Shape and form in plants and fungi (Ed. by D.S. Ingram \& A.J. Hudson), Academic Press, London. pp. 17-38.

MANN D.G. \& Evans M.K. 2007. Molecular genetics and the neglected art of diatomics. In: Unravelling the algae - the past, present and future of algal molecular systematics (Ed. by J. Brodie \& J.M. Lewis), CRC Press, Boca Raton, FL, USA. pp. 232-266.

MANN D.G. \& STICKLE A.J. 1993. Life history and systematics of Lyrella. Nova Hedwigia, Beiheft 106: 43-70.

Mann D.G., Chepurnov V.A. \& IDEI M. 2003. Mating system, sexual reproduction and auxosporulation in the anomalous raphid diatom Eunotia (Bacillariophyta). Journal of Phycology 39: $1067-1084$

Medin L.K. \& KaczmarskA I. 2004. Evolution of the diatoms: V. Morphological and cytological support for the major clades and a taxonomic revision. Phycologia 43: 245-270.

Medlin L.K., Crawford R.M. \& Andersen R.A. 1986. Histochemical and ultrastructural evidence for the function of the labiate process in the movement of centric diatoms. British Phycological Journal 21: 297-301.

Medlin L., Elwood H.J., Stickel S. \& Sogin M.L. 1988. The characterization of enzymatically amplified eukaryotic 16S-like rRNA coding regions. Gene 71: 491-499.

Medlin L.K., Kooistra W.H.C.F. \& Schmid A.M.-M. 2000. A review of the evolution of the diatoms - a total approach using molecules, morphology and geology. In: The origin and early evolution of the diatoms: fossil, molecular and biogeographical approaches (Ed. by A. Witkowski \& J. Sieminska), Szafer Institute of Botany, Polish Academy of Science, Cracow, Poland. pp. 13-35.

Medlin L.K., Jung I., Bahulikar R., Mendgen K., Kroth P. \& Kooistra W.H.C.F. 2008a. Evolution of the diatoms. VI. Assessment of the new genera in the araphids using molecular data. Nova Hedwigia 133: 81-100.

Medlin L.K., Sato S., Mann D.G. \& Kooistra W.H.C.F. 2008 b. Molecular evidence confirms sister relationship of Ardissonea, Climacosphenia and Toxarium within the bipolar centric diatoms (Bacillariophyta, Mediophyceae) and cladistic analyses confirms that extremely elongated shape has arisen twice in the diatoms Journal of Phycology: in press.

Morales E. 2001. Morphological studies in selected fragilarioid diatoms (Bacillariophyceae) from Connecticut waters (U.S.A.) Proceedings of the Academy of Natural Sciences of Philadelphia 151: $39-54$.

Morales E. 2005. Observations of the morphology of some known and new fragilarioid diatoms (Bacillariophyceae) from rivers in the USA. Phycological Research 53: 113-133.

Nagumo T. 2003. Taxonomic studies of the subgenus Amphora Cleve of the genus Amphora (Bacillariophyceae) in Japan. Bibliotheca Diatomologica 49: 1-265.

Nagumo T. \& Kobayashi H. 1990. The bleaching method for gently loosening and cleaning a single diatom frustule. Diatom 5: $45-50$.

Navarro N.J. \& Williams D.M. 1991. Description of Hyalosira tropicalis sp. nov. (Bacillariophyta) with notes on the status of Hyalosira Kützing and Microtabella Round. Diatom Research 6: 327-336.

Pickett-Heaps J.D., Hill D.R.A. \& Wetherbee R. 1986. Cellular movement in the centric diatom Odontella sinensis. Journal of Phycology 22: 334-339.

Pickett-Heaps J.D., Schmid A.-M.M. \& Edgar L.A. 1990. The cell biology of diatom valve formation. Progress in Phycological Research 7: 1-168.

Posada D. \& Crandall K.A. 1998. Modeltest: testing the model of DNA substitution. Bioinformatics 14: 817-818. 
PouličKovÁ A. \& MANN D.G. 2006. Sexual reproduction in Navicula cryptocephala (Bacillariophyceae). Journal of Phycology 42: 872-886.

Poulíč́ová A., Mayama S., Chepurnov V.A. \& Mann D.G. 2007. Heterothallic auxosporulation, incunabula and perizonium in Pinnularia (Bacillariophyceae). European Journal of Phycology 42: $367-390$

Ronquist F. \& HuelsenbeCK J.P. 2003. MrBayes 3: Bayesian phylogenetic inference under mixed models. Bioinformatics 19: $1572-1574$

Roshchin A.M. 1994. Zhiznennye tsikly diatomovykh vodoroslej. Naukova Dumka, Kiev. 170 pp.

Ross R., Cox E.J., Karayeva N.I., Mann D.G., Paddock T.B.B., SimONSEN R. \& Sims P.A. 1979. An amended terminology for the siliceous components of the diatom cell. Nova Hedwigia, Beiheft 64: 513-533.

Round F.E., Crawford R.M. \& MANn D.G. 1990. The diatoms: biology and morphology of the genera. Cambridge University Press, Cambridge, UK. 747 pp.

Round F.E., Hallsteinsen H. \& PaAsche E. 1999. On a previously controversial "fragilarioid" diatom now placed in a new genus Nanofrustulum. Diatom Research 14: 343-356.

Sato S., Nagumo T. \& Tanaka J. 2004. Auxospore formation and the morphology of the initial cell of the marine araphid diatom Gephyria media (Bacillariophyceae). Journal of Phycology 40: 684-691

Sato S., Mann D.G., Nagumo T., Tanaka J. \& Medlin L.K. 2008a. Life cycle of Grammatophora marina (Bacillariophyta) with special reference to its auxospore fine structure. Phycologia 47: 12-27.

Sato S., Kuriyama K., Tadano T. \& Medlin K.L. 2008 b. Auxospore fine structure in a marine araphid diatom Tabularia parva (Bacillariophyta). Diatom Research. In press.

SCHMID A.-M.M. 1994. Aspects of morphogenesis and function of diatom cell walls with implications for taxonomy. Protoplasma 181: 43-60.

SCHMid A.-M.M. \& CRAwFord R.M. 2001. Ellerbeckia arenaria (Bacillariophyceae): formation of auxospores and initial cells. European Journal of Phycology 36: 307-320.

Shull V.L., Vogler A.P., BaKer M.D., Maddison D.R. \& HAMMOND P.M. 2001. Sequence alignment of $18 \mathrm{~S}$ ribosomal RNA and the basal relationships of adephagan beetles: evidence for monophyly of aquatic families and the placement of Trachypachidae. Systematic Biology 50: 945-969.

Sims P.A. \& Holmes R.W. 1983. Studies on the "kittonii" group of Aulacodiscus species. Bacillaria 6: 267-292.

Sims P.A., Mann D.G. \& Medlin L.K. 2006. Evolution of the diatoms: insights from fossil, biological and molecular data. Phycologia 45: 361-402.

SorhanNus U. 2004. Diatom phylogenetics inferred based on direct optimization nuclear-encoded SSU rRNA sequences. Cladistics 20: 487-497.

Sorhannus U. 2007. A nuclear-encoded small-subunit ribosomal RNA timescale for diatom evolution. Marine Micropaleontology 65: $1-12$.

Stamatakis A., Ludwig T. \& Meier H. 2005. RAxML-III: a fast program for maximum likelihood-based inference of large phylogenetic trees. Bioinformatics 21: 456-463.
Sullivan M.J. \& Currin C.A. 2000. Community structure and functional dynamics of benthic microalgae in salt marshes. In: Concepts and controversies in tidal marsh ecology (Ed. by M.P. Weinstein \& D.A. Kreeger), Kluwer Academic Publishers, Dordrecht, Germany. pp. 81-106.

SWOFFORD D.L. 2002. PAUP*: phylogenetic analysis using parsimony (* and other methods), ver. 4.0b10. Sinauer Associates, Sunderland, MA, USA.

Thompson J.D., Gibson T.J., Plewniak F., Jeanmougin F. \& Higgins D.G. 1997. The ClustalX windows interface: flexible strategies for multiple sequence alignment aided by quality analysis tools. Nucleic Acids Research 24: 4876-4882.

TIFFANY M.A. 2005. Diatom auxospore scales and early stages in diatom frustule morphogenesis: their potential for use in nanotechnology. Journal of Nanoscience and Nanotechnology 5: 131-139.

Toyoda K., Idei M., Nagumo T. \& Tanaka J. 2005. Finestructure of frustule, perizonium and initial valve of Achnanthes yaquinensis McIntire and Reimer (Bacillariophyceae). European Journal of Phycology 40: 269-279.

Toyoda K., Williams D.M., Tanaka J. \& Nagumo T. 2006 Morphological investigations of the frustule, perizonium and initial valves of the freshwater diatom Achnanthes crenulata Grunow (Bacillariophyceae). Phycological Research 54: 173-182.

Trobajo R., Mann D.G., Chepurnov V.A., Clavero E. \& Cox E.J. 2006. Auxosporulation and size reduction pattern in Nitzschia fonticola (Bacillariophyta). Journal of Phycology 42: 1353-1372.

Underwood G.J.C. \& KRomKamp J. 1999. Primary production by phytoplankton and microphytobenthos in estuaries. Advances in Ecological Research 29: 93-153.

Van De Peer, Y., Caers A., De Rijk P. \& De Wachter R. 1998. Database on the structure of small ribosomal subunit RNA Nucleic Acids Research 26: 179-182.

Van de Peer Y., Neefs J.-M., De Rijk P. \& De Wachter R. 1993. Reconstructing evolution from eukaryotic small-ribosomal-subunit RNA sequences: calibration of the molecular clock. Journal of Molecular Evolution 37: 221-232.

VAN LANDINGHAM S.L. 1978. Catalogue of the fossil and recent genera and species of diatoms and their synonyms. Part VII. Rhoicosphenia through Zygoceros. J. Cramer, Vaduz, Liechtenstein.

von Stosch H.A. 1962. Über das Perizonium der Diatomeen. Vorträge aus dem Gesamtgebiet der Botanik 1: 43-52.

von STOSCH H.A. 1982. On auxospore envelopes in diatoms. Bacillaria 5: 127-156.

von Stosch H.A. \& Kowallik K.V. 1969. Der von Geitler aufgestellte Satz über die Notwendigkeit einer Mitose für jede Schalenbildung von Diatomeen. Beobachtung über die Reichweite und Überlegungen zu seiner zellmechanischen Bedeutung. Österreichische botanische Zeitschrift 116: 454-474.

von Stosch H.A., Theil G. \& Kowallik K.V. 1973. Entwicklungsgeschichtliche Untersuchungen an zentrischen Diatomeen. V. Bau und Lebenszyklus von Chaetoceros didymum, mit Beobachtungen über einige andere Arten der Gattung. Helgoländer wissenschaftliche Meeresuntersuchungen 25: 384445.

Witkowski A., Lange-Bertalot H. \& Metzeltin D. 2000 Diatom flora of marine coasts I. Iconographia Diatomologica 7 : $1-925$.

Received 12 January 2008; accepted 18 February 2008 Associate editor: Wiebe Kooistra 